\title{
Grain-Scale Analysis of Solid-Phase Organic Matter and Arsenic Mobility in Mining-Impacted 1 Sediment from SubखArctic Lakes, Northwest Territories, Canada
}

Clare B Miller ( $\nabla$ clare.miller@utas.edu.au )

University of Tasmania https://orcid.org/0000-0003-3241-0314

Michael B Parsons

Geological Survey of Canada Atlantic

Heather E Jamieson

Queens University

Omid H Ardakani

Geological Survey of Canada Calgary

R Timothy Patterson

Carleton University

Jennifer M Galloway

Geological Survey of Canada Calgary

\section{Research Article}

Keywords: Arsenic speciation, mine waste, climate change, contaminant mobility, environmental monitoring

Posted Date: August 9th, 2021

DOI: https://doi.org/10.21203/rs.3.rs-718116/v1

License: (c) (i) This work is licensed under a Creative Commons Attribution 4.0 International License. Read Full License 
Grain-scale analysis of solid-phase organic matter and arsenic mobility in mining-impacted

2 sediment from sub-Arctic lakes, Northwest Territories, Canada

3 Clare B. Miller ${ }^{\mathrm{a}, \mathrm{b}^{*}}$, Michael B. Parsons ${ }^{\mathrm{b}, \mathrm{c}}$, Heather E. Jamieson ${ }^{\mathrm{b}}$, Omid H. Ardakani ${ }^{\mathrm{d}}$, R. Timothy

4 Patterson ${ }^{\mathrm{e}}$, Jennifer M. Galloway,

$5 \quad{ }^{\text {a }}$ Centre for Ore Deposit and Earth Sciences (CODES), University of Tasmania, Hobart TAS 7001,

6 Australia.

$7 \quad{ }^{\mathrm{b}}$ Department of Geological Sciences and Geological Engineering, Queen's University, Kingston, ON,

8 K7L 3N6, Canada

$9 \quad{ }^{c}$ Geological Survey of Canada/Commission geologique du Canada, Natural Resources

10 Canada/Ressources naturelles Canada, 1 Challenger Drive, Dartmouth, NS, B2Y 4A2, Canada

$11{ }^{\mathrm{d}}$ Geological Survey of Canada/Commission géologique du Canada, Natural Resources

12 Canada/Ressources naturelles Canada, 3303 - 33 Street N.W. Calgary, AB, T2L 2A7, Canada

$13{ }^{\mathrm{e}}$ Ottawa-Carleton Geoscience Centre and Department of Earth Sciences, Carleton University, Ottawa, ON, 14 KIS 5B6, Canada

$15 *$ Corresponding author. Tel +61 362262425 E-mail address: clare.miller@utas.edu.au (C.B. Miller)

16 ORCID 0000-0003-3241-0314

17 Acknowledgements

18 This project was jointly funded by Polar Knowledge Canada (Project\# 1519-149, to JMG and RTP 19 (Carleton University)), the Environmental Geoscience Program, Natural Resources Canada (Metal

Mining Project, MBP; Northern Baselines Activity, JMG), a Natural Sciences and Engineering Research Council of Canada (NSERC) Discovery Grant (HEJ; RGPIN/03736-2016), a NSERC Northern Research Supplement (HEJ; RGPNS/305500-2016), the NSERC Create Mine of Knowledge (CBM, Principle Investigator: Marc Amyot, Université de Montréal) and the Northern Scientific Training programs (CBM, Project \# 306001). Field programs were conducted under Aurora Research Institute License No. 15858 (JMG) and supported by CIRNAC (Murray Somers and Joel Gowman). Synchrotron-based analyses were performed at GeoSoilEnviroCARS (GSECARS; The University of Chicago, Sector 13) and Sector 20 at the APS, Argonne National Laboratory. The authors would like to thank Nawaf Nasser, Braden Gregory, Seabridge Gold (Brent Murphy), Agatha Dobosz (Queen's Facility for Isotope Research (QFIR)), Brian Joy 31 Consulting) and Anežka Borbina-Radková (Queen's University). CBM contributed to the final 32 draft of this manuscript in affiliation with CODES, UTAS, Australia. This is Contribution Number 20200025 of the Lands and Minerals Sector, Natural Resources Canada. 
Abstract

Arsenic (As) is commonly sequestered at the sediment-water interface (SWI) in miningimpacted lakes through adsorption and/or co-precipitation with authigenic iron (Fe)-

37 (oxy)hydroxides or sulphides. The results of this study demonstrate that the accumulation of solidphase organic matter $(\mathrm{OM})$ in near-surface sediments also influences the mobility and fate of As in sub-Arctic lakes. Sediment gravity cores, sediment grab samples, and porewaters were collected from three lakes downstream of the former Tundra gold mine, Northwest Territories. Analysis of

41 sediment using combined micro-X-ray fluorescence/diffraction, K-edge X-ray Absorption NearEdge Structure (XANES), and organic petrography shows that As is associated with both aquatic (benthic and planktonic alginate) and terrestrially-derived OM (cutinite; funginite). Most As is

44 hosted by fine-grained Fe-(oxy)hydroxides or sulphide minerals (e.g., goethite, orpiment, lepidocrocite, mackinawite); however, grain-scale synchrotron-based analysis shows that As is also associated with amorphous OM. Mixed As oxidation states in porewater (median $=62 \%$ As $(\mathrm{V}), 18 \%$ As (III); $n=20)$ and sediment (median $=80 \%$ As (-I) and (III), $19 \%$ As $(\mathrm{V}) ; n=9)$ indicate the presence of variable redox conditions in the near-surface sediment and suggest that post-depositional remobilization of As has occurred. Detailed characterization of As-bearing OM at and below the SWI suggests that OM plays an important role in stabilizing redox-sensitive authigenic minerals and associated As. Based on these findings, it is expected that increased concentrations of labile OM will drive post-depositional surface-enrichment of As in miningimpacted lakes and may increase or decrease As flux from sediments to overlying surface waters.

\section{Keywords}




\subsection{Introduction}

Twenty-first century climate warming has disproportionately affected high northern latitudes, causing greater and more rapid increases in temperature and duration of ice-free seasons

60 relative to lower latitudes (ACIA, 2005). This warming has promoted increased primary

61 production and transport of terrigenous OM to northern lakes (Frey and McClelland, 2009; Prowse

62 et al., 2011; Stern et al., 2012; Griffiths et al., 2017). The enhanced flux of OM influences the

63 biogeochemistry and redox dynamics of near-surface lake sediments (Toevs et al., 2006; McGuire

64 et al., 2009; Rantala et al., 2016; Outridge et al., 2017), and in particular, the mobility of redox-

65 sensitive elements such as As (Martin and Pedersen, 2002; Wang and Mulligan, 2006). Lakes

66 affected by gold mining activities already have elevated concentrations of As in sediments due to

67 input from tailings, waste rock, effluent, airborne emissions, windblown dusts, and/or mineralized

68 bedrock (DeSisto et al., 2011; Craw and Bowell, 2014; Galloway et al., 2015, 2018; Miller et al.,

69 2019; Palmer et al., 2019). Changing redox conditions in the water column and near-surface

70 sediments driven by seasonal variations and longer-term changes associated with increased OM

71 flux can cause the release of As from sediments to overlying surface waters (Martin and Pedersen,

72 2002; Bauer and Blodau, 2006; Couture and Van Cappellen, 2011; Anawar et al., 2013; Barrett et

73 al., 2019; Palmer et al., 2019; Schuh et al., 2019). The influence of dissolved OM (DOM) and

74 changing redox conditions on the geochemical cycling of As is well documented (e.g., Redman et 75 al., 2002; Bauer and Blodau, 2006; Mladenov et al., 2015; Lawson et al., 2016); however, the role 76 of solid-phase OM (i.e., OM > 0.22 to $0.45 \mu \mathrm{m}$ ) is not as well understood (Langner et al., 2011;

77 Anawar et al., 2013; Biswas et al., 2019), especially in lakes (Galloway et al., 2018). As climate 78 warming continues to impact sensitive sub-Arctic and Arctic ecosystems, an improved 
understanding of the effects of increasing OM on the long-term stability of As is needed to predict the impacts of future climate variations on As mobility in northern lake environments.

The post-depositional mobility of As in lacustrine sediment is governed by the solid-phase speciation of As, which depends primarily on the redox conditions of the sediment and associated porewaters (Smedley and Kinniburgh, 2002). Under oxic conditions, As is sequestered through adsorption and co-precipitation with authigenic and detrital Fe- and manganese (Mn)(oxy)hydroxides at the sediment water interface (SWI; Dixit and Hering, 2003). Development of reducing conditions, through burial in the sediment column or increased abundance of labile OM that consumes oxygen $\left(\mathrm{O}_{2}\right)$ upon decay, allows for the sequestration of dissolved As through sorption and co-precipitation reactions involving authigenic sulphides (Farquhar and Livens, 2002; Bostick et al., 2005; Lowers et al., 2007; Le Pape et al., 2017; Schuh et al., 2019). The development transition zone in the upper sediment column, in the hypolimnion of seasonally stratified lakes or, in some cases, under prolonged ice cover (e.g., Palmer et al., 2019). At this redox interface, decreasing concentrations of available $\mathrm{O}_{2}$ result in the release of As through reductive dissolution of Fe- and Mn-(oxy)hydroxides (Wolthers et al., 2005; Bennett et al., 2012; An et al., 2017). Under changing redox conditions, the formation of organo-mineral aggregates (OMAs) and/or Fe monosulphides (FeS; e.g., mackinawite) may promote the sequestration of metal(loid)s (e.g., As, $\mathrm{Cu}, \mathrm{Cd}, \mathrm{Ni}, \mathrm{Pb}, \mathrm{Zn}$ ) through co-precipitation with, or sorption to, these authigenic phases. However, the effectiveness of these mechanisms in sequestering elements from bottom waters to sediments in natural environments is difficult to predict (Moon and Peacock, 2012; Chen et al., 100 2014; Kleber et al., 2015; An et al., 2017; Vega et al., 2017; Du et al., 2018; Qu et al., 2019). 
Although there is little published data on the nature or origin of solid-phase OM in lake

102

103

104

105

106

107

108

109

110

111

112

113

114

115

116

117

118

119

120

121

122

123 sediments or its influence on element mobility in these settings, there is a growing consensus that solid-phase OM plays an important role in the mobility of As in other low-temperature environmental systems (e.g., peat bogs, deltaic sediments, soils, lakes) (Langner et al., 2011; Galloway et al., 2018; Wang et al., 2018; Biswas et al., 2019). In these environments, As binding to OM may occur via ternary complexes through the formation of a metal-cation bridge (i.e. Fe (III), Al (III), Ca (II)) (Ritter et al., 2006; Sharma et al., 2010; Hoffmann et al., 2013), thiol-bonding to sulphydryl groups of OM (Langner et al., 2011; Wang et al., 2018), or complexation with the oxygen-containing functional groups of OM (Tessier et al., 1996; Biswas et al., 2019). The role of solid-phase OM in the sequestration of As may be of particular importance under transitional redox conditions where Fe reduction and $\mathrm{S}$ oxidation occur simultaneously and As is susceptible to remobilization. Characterization of both the mineralogical and biogeochemical processes that regulate the mobility of As in mining-impacted, freshwater aquatic systems is necessary to inform the monitoring and remediation of these environments.

Arsenic concentrations in many lakes surrounding former gold mine sites in northern Canada are elevated above Canadian Council of Ministers of the Environment (CCME) guidelines and regional background due to historical mining activities (Wagemann et al., 1978; Bright et al., 1994, 1996; Groves et al., 1998; Andrade et al., 2010; Galloway et al., 2012, 2015, 2018; Palmer et al., 2015, 2019, 2021; Jamieson et al., 2017; Schuh et al., 2018, 2019; Miller et al., 2019). Previous work (Galloway et al., 2018; Miller et al., 2019, 2020) shows that labile OM affects As mobility and fate through its influence on the redox environment of near-surface sediment and long-term stability of As-bearing minerals. However, the grain-scale associations between As and solid-phase OM have not been studied in detail and are important for determining the mechanism 
124 of solid OM control on As mobility. This study aims to address the knowledge gaps presented in

125 Galloway et al. (2018) and Miller et al. (2019, 2020) and focuses specifically on determination of

126 the origin of the solid-phase OM in lake sediments, and the variable influence of aquatic- and

127 terrigenous-derived OM on the mobility of As in three mining-impacted, sub-Arctic lakes located

128 in the central Northwest Territories (NT), Canada.

129

130

\subsection{Study Area and Previous Work}

The study area is the former Tundra Mine, which is located in the central portion of the Slave Geological Province of the Canadian Shield and is $80 \mathrm{~km}$ north of the present-day tree line (Fig. 1). The area is part of the transition zone between discontinuous and continuous permafrost with numerous small lakes and organic deposits occurring in low-lying areas (Seabridge Gold Inc., 2010; Karunaratne, 2011; AECOM, 2015). Small lakes, such as those investigated in this study, may be ice-covered from mid-October to late June (Palmer et al., 2019).

The former Tundra and Salmita mines are approximately $240 \mathrm{~km}$ NE of Yellowknife, NT, Canada (Fig. 1). Approximately 285,000 oz of gold were produced at grades ranging from 18.4 to $27.8 \mathrm{~g} \cdot \mathrm{t}^{-1}$ were produced during two phases of mining, from 1964 to 1968 and 1983 to 1987 (Ransom and Robb, 1986; Silke, 2009). Ore was processed at the Tundra Mine facilities and wastes were deposited into an adjacent lake (location of Tailings Confinement Area (TCA); Fig. 1). During the second period of mining, tailings-core dams were built to reinforce this lake and create a tailings confinement area (Fig. 1). The Tundra Mine site has been in care and maintenance since 1999 under the stewardship of the Contaminants and Remediation Directorate (CARD) of CrownIndigenous Relations and Northern Affairs Canada (CIRNAC). At the beginning of remediation activities in 2007, approximately $155,000 \mathrm{~m}^{3}$ of waste rock, $240,000 \mathrm{~m}^{3}$ of tailings, and 1,280,000 $\mathrm{m}^{3}$ of impacted water were present on-site (URS, 2005; Golder Associates Ltd., 2008). In lakes 
147 surrounding the tailings impoundment at the Tundra Mine site, As concentrations in surface water 148 range from 0.80 to $105 \mu \mathrm{g} \cdot \mathrm{L}^{-1}$ and from 24 to $1,010 \mathrm{mg} \cdot \mathrm{kg}^{-1}$ in near-surface sediments (Staples, 149 2014; Miller et al., 2019). Arsenic concentrations in the near-surface sediment of all five lakes 150 sampled by the authors in 2016 exceed the CCME Interim Sediment Quality Guideline (ISQG; 5.9 $151 \mathrm{mg} \mathrm{kg}{ }^{-1}$ ) and Probable Effect Level (17 $\mathrm{mg} \mathrm{kg}^{-1}$; CCME, 2001a, 2001b). The disposal of waste 152 rock, overtopping and seepage of tailings ponds, weathering and airborne deposition of waste rock 153 and tailings, discharge of treated tailings effluent, and natural weathering of mineralized bedrock 154 have all contributed to the elevated As concentrations in lakes around the former Tundra Mine 155 (Miller et al., 2019). The site is currently in an adaptive management and long-term monitoring 156 phase, following the completion of remediation activities in August 2018 (AECOM, 2018). The 157 oxidation of mining-derived sulphides (e.g., arsenopyrite) and authigenic As-bearing framboidal 158 pyrite are the predominant sources of increased porewater As concentrations in the near-surface 159 sediment of Bulldog Lake. Conversely, in Hambone and Powder Mag lakes, the seepage and 160 overflow of tailings waters and disposal of treated effluent contributed As, in dissolved or 161 suspended form, to the near-surface sediment. Despite the oxic nature of the overlying surface 162 waters of Bulldog $\left(\mathrm{DO}=7.80 \mathrm{mg} \cdot \mathrm{L}^{-1}\right)$ and Powder Mag $\left(\mathrm{DO}=3.60 \mathrm{mg} \cdot \mathrm{L}^{-1}\right)$ lakes, the presence of 163 mixed As oxidation states in both the aqueous and solid-phase suggests that the contaminant source 164 and sediment redistribution processes have influenced the post-depositional mobility of As and 165 associated redox species $(\mathrm{Fe}, \mathrm{S})$ at the SWI despite oxygenated conditions at mid-water column 166 depths (Martin and Pedersen 2002; Miller et al., 2019; Schuh et al., 2019). Due to their shallow 167 nature, it is unlikely these lakes are stratified. 
170 Sediment grab samples were collected from Hambone Lake $\left(64.047033^{\circ} \mathrm{N}, 111.154958^{\circ} \mathrm{W}\right)$ in

171 July 2016 (Fig. 1). Mean sedimentation rates in the near-surface sediment of Powder Mag (52

$\left.172 \mathrm{yr} \cdot \mathrm{cm}^{-1}\right)$ and Bulldog $\left(40 \mathrm{yr} \cdot \mathrm{cm}^{-1}\right)$ lakes are higher than average for regional lakes $\left(70 \mathrm{yr} \cdot \mathrm{cm}^{-1}\right.$;

173 Crann et al., 2015) and this increased sedimentation rate is attributed to mining activities at Tundra

174 and Salmita mines and associated landscape disturbance (Miller et al., 2019).

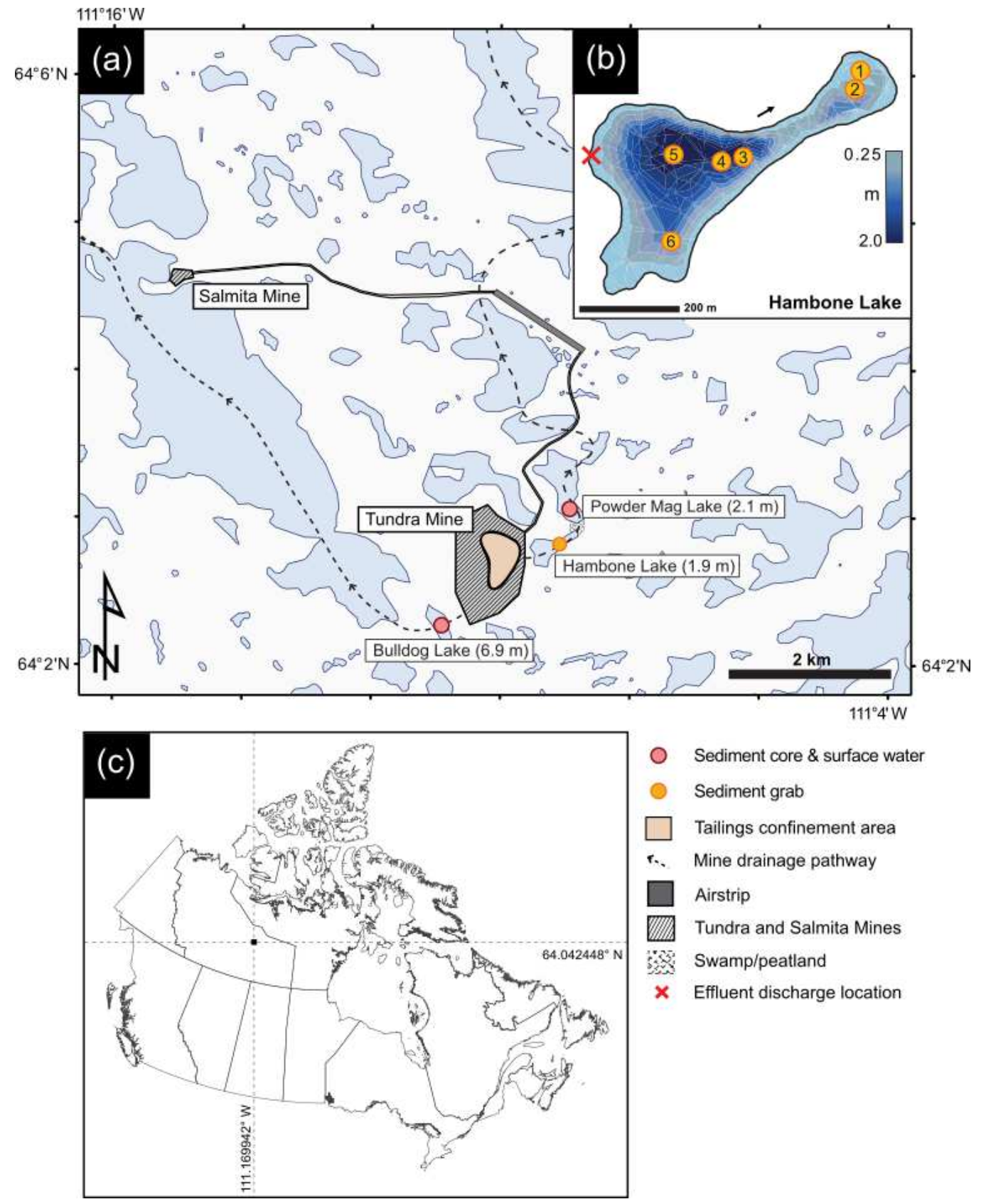


Fig. 1. Map showing a) Sampling locations and predominant mine drainage pathways originating from the former Tundra Mine site, and maximum lake depths (in parentheses); b) Bathymetry map of Hambone Lake with numbered locations of sediment grab samples (modified from Miller et al., 2019); c) Study location, dashed lines in (a) denote surface water flow paths from the former Tundra Mine site (INAC, 2005; figure after Miller et al. (2019)).

\subsection{Methods and Materials}

\subsection{Sample collection and preparation}

Sediment cores were collected from the frozen surface of Powder Mag and Bulldog lakes using a gravity corer with polycarbonate core tubes $(7.5 \times 60 \mathrm{~cm})$. All sediment cores were collected from the deepest location in each lake to sample the zone of accumulation (Blais and Kalff, 1995). Immediately following collection, cores were vertically extruded and sub-sampled at 1 -cm resolution in a glove bag filled with high purity $(99.998 \%)$ nitrogen $\left(\mathrm{N}_{2}\right)$ in the field. Sediment was sub-sampled into $\mathrm{N}_{2}$-flushed $50 \mathrm{~mL}$ polypropylene centrifuge tubes (Corning® Falcon ${ }^{\circledR)}$ ) and refrigerated prior to shipment to the Geological Survey of Canada-Atlantic (GSCA) in Dartmouth, Nova Scotia, for porewater extraction. Near-surface (0 to $15 \mathrm{~cm}$ ) sediment grab samples were collected from Hambone Lake using an Ekman dredge sampler and homogenized prior to analysis. These sediment samples were frozen and sent to Queen's University, Kingston, Ontario, for sub-sampling and preparation. Aliquots of sediment were freeze-dried at $1.0 \mathrm{~Pa}$ and $50{ }^{\circ} \mathrm{C}$ for organic geochemistry and petrography $(0.5 \mathrm{~g})$ and inorganic geochemical analyses $(0.5$ g). A separate aliquot was dried in a glove bag filled with high purity $\mathrm{N}_{2}$ to preserve solid-phase As speciation (Huang and Ilgen, 2006). This $\mathrm{N}_{2}$-dried material was used for scanning electron microscope (SEM)-based automated mineralogy, electron microprobe analysis (EPMA), synchrotron-based bulk XANES, micro X-ray fluorescence ( $\mu$-XRF), and micro X-ray diffraction ( $\mu$-XRD) to determine the mineralogy of As-bearing hosts and As speciation in the sediments of lakes sampled near Tundra Mine. 
Porewater was extracted from the sediment core subsamples by centrifugation (Thermo

201 Scientific Sorvall Legend ${ }^{\mathrm{TM}}$ XF Centrifuge). Samples were prepared and handled following the

202 protocol detailed in Miller et al. (2019) for filtered cations, filtered anions, total As, and total

203 inorganic As speciation. For each sample, $\mathrm{pH}$ was measured with a hand-held $\mathrm{pH}$ meter $(\mathrm{HACH}$

204 H138 MiniLab ISFET). Due to low water content, Eh could not be measured.

$205 \quad 3.2 \quad$ Sediment and porewater geochemistry

Metal(loid) concentrations in porewaters were measured at the Inorganic Geochemical

207 Research Laboratory of the Geological Survey of Canada in Ottawa. Analyses of major elements

208 were performed by Inductively Coupled Plasma - Atomic Emission Spectroscopy (ICP-AES)

209 using a Perkin-Elmer 3000 DV. Trace elements were analyzed using Inductively Coupled Plasma

210 - Mass Spectroscopy (ICP-MS) with a Thermo Corporation X-7 Series II. Relative standard

211 deviation (RSD) ranges from $0.08 \%$ to $1.40 \%$ and mean percent difference (MPD) ranges from

$2120.12 \%$ to $1.98 \%$ for As in laboratory duplicates. Unfiltered field duplicates demonstrate higher

213 RSD and MPD (2.44\% and 3.45\%, respectively) than filtered duplicates (2.05\% and $2.90 \%)$.

214 Arsenic was below detection limit $\left(0.1 \mu \mathrm{g} \cdot \mathrm{L}^{-1}\right)$ in all field blanks $(n=4)$.

The relative proportions of dissolved As (V), As (III), and a residual fraction (AsR) in water

216 samples were determined by hydride generation-atomic fluorescence spectrometry (HG-AFS;

217 model PSA 10.055 Millennium Excalibur) at the Université de Montréal. The residual fraction

218 likely includes As species that are not detected using HF-AFS, including thioarsenates in sulfidic

219 waters and non-reducible organoarsenic compounds (Planer-Friedrich and Wallschläger, 2009; PS

220 Analytical, 2018).

221 Element concentrations in sediment samples $(n=211)$ were determined by ICP-MS

222 (1F/AQ250 package) following digestion by a modified aqua regia treatment (1:1:1 
224 Columbia. Partial digestion with aqua regia was used as key elements of interest (i.e. As and S)

225 may be lost through volatilization in more aggressive, near-total digestions (Parsons et al., 2012,

226 2019). In blind duplicate samples, relative standard deviation (RSD) ranged from $0.21 \%$ to 7.22

$227 \%$ and mean percent difference (MPD) ranged from $0.29 \%$ to $10.21 \%$ for As. A certified reference

228 material (STSD-3; Lynch, 1990) was included with each sample set. The mean measured As

229 concentration in STSD-3 was $24.34 \pm 0.81 \mathrm{mg} \cdot \mathrm{kg}^{-1}(n=8) \mathrm{vs}$. an expected concentration of $22 \pm$

$2306 \mathrm{mg} \cdot \mathrm{kg}^{-1}$ for As following aqua regia digestion (RSD $\left.3.3 \%\right)$. Mean sulphur concentration (0.15

$231 \pm 0.01 \% ; n=8)$ was within the standard deviation of the certified value $(0.14 \pm 0.04 \%)$.

\section{$232 \quad 3.3 \quad$ Solid-phase organic matter characterization}

The amount and type of OM in sediments (Hambone Lake $n=6$; Powder Mag Lake $n=$

234 30; Bulldog Lake $n=37$ ) was determined by Rock-Eval $6^{\circledR}$ programmed pyrolysis at the 235 Geological Survey of Canada, Calgary (Lafargue et al., 1998). In duplicate samples, RSD ranges 236 from 0 to $9 \%$ and MPD ranges from 0 to $13 \%$ for the organic constituents of interest (S1, S2, S3, 237 TOC). Further details regarding sample preparation, methodologies, and analytical precision are 238 provided in Supplemental data SM1. Particle size analysis for near-surface sediment is presented 239 in Miller et al., (2019).

In recent sediments, the $\mathrm{S} 1$ fraction of $\mathrm{OM}$ is comprised of aquatic-derived $\mathrm{OM}$ (e.g., algal-

241 derived lipids; amino acids, chlorophyll, small volatile molecules, a fraction of humic material, 242 and proteins and other macromolecules) and S2 compounds are derived from the 243 biomacromolecule structure of algal cell walls and other aquatic biological matter, such as 244 phytoplankton and copepods (Sanei et al., 2005; Carrie et al., 2012). Terrestrial plant materials 
245 (i.e. conifer needles, roots, bark), in addition to humic and fulvic acids, comprise the S3 fraction

246 (Carrie et al., 2012; Albrecht et al., 2015).

247 The distribution and origin of solid-phase OM was assessed using polished, 1-cm epoxy

248 mounts $(n=5)$ and qualitative petrographic analysis following methods outlined by Reyes et al.

249 (2006). Incident white light and fluorescent light microscopy were conducted using a Zeiss

250 Axioimager II microscope system (50× magnification) equipped with the Diskus-Fossil system.

251 Fluorescence microscopy was conducted using ultraviolet G $365 \mathrm{~nm}$ excitation with a $420 \mathrm{~nm}$

252 filter. Organic matter was characterized based on the classification of macerals in International

253 Committee for Coal Petrology (1971), Sanei et al. (2005), and Reyes et al. (2006).

254 Comparison of optical properties (using fluorescence spectrometry) between samples that

255 had and had not previously been examined using SEM and EPMA analysis suggests that exposure

256 to an electron beam resulted in thermal alteration of the OM. Similar alteration of OM in lithified

257 rocks by ion milling was demonstrated by Sanei and Ardakani (2016) but, to the best of our

258 knowledge, the effects of prolonged electron beam exposure on OM in unconsolidated sediment

259 have not been investigated. As a result, SEM/EPMA analysis and organic petrography were

260 conducted on different sub-samples from the same sediment interval.

$261 \quad 3.4 \quad$ Solid-phase As speciation analysis

262 Eleven $\mathrm{N}_{2}$-dried lake sediment samples (Hambone Lake $n=3$; Powder Mag Lake $n=4$;

263 Bulldog Lake $n=4$ ) were selected for detailed As speciation analysis based on bulk elemental

264 composition and position within each core. Polished thin sections (35 to $50 \mu \mathrm{m}$ thickness) were

265 prepared at Vancouver Petrographics following specifications by Schuch et al., 2018. 


\subsubsection{SEM-based Automated Mineralogy and Electron Microprobe analyses}

The relative distribution of As-hosting solid-phases in selected sediment samples was completed through automated mineralogy, using a FEI ${ }^{\mathrm{TM}}$ Quanta 650 Field Emission Gun Environmental SEM, and Mineral Liberation Analyzer software. This integrated technique quantifies mineral phases through a combination of backscatter electron (BSE) image analysis and energy-dispersive X-ray spectroscopy (EDS) (Buckwalter-Davis, 2013). Miller et al. (2019) describe the operating conditions, the mineral reference library used for phase classification, and the calculations used to quantify the relative contribution of each As-hosting phase. Sparse phase liberation (SPL) analysis mode with a user-defined BSE greyscale range (120 to 255) was used to selectively identify As-hosting phases but does not provide bulk mineralogy information (Fandrich et al., 2007). Fine-grained aggregates of poorly crystalline, As-bearing Fe-sulphides and Fe(oxy)hydroxides $\left(\mathrm{FeS}_{\mathrm{x}} / \mathrm{FeO}\right)$, identified by Miller et al. (2019), co-occur with $\mathrm{OM}$ and were targeted for analysis using a JEOL JXA-8230 electron microprobe operating in wavelengthdispersive (WDS) mode. The small size of these grains and uneven topography of the polished surface can cause X-ray scattering and inaccurate peak intensity (Rönnhult et al. 1987), therefore, the EPMA results are considered semi-quantitative.

\subsubsection{Synchrotron-based $\mu-X R F$ and $\mu-X R D$}

Arsenic-bearing grains associated with solid-phase OM were identified through combined SEM-based automated mineralogy, EPMA, and fluorescent light microscopy analysis. These grains were subsequently targeted for synchrotron-based $\mu-X R F$ and $\mu-X R D$ analysis using microfocused X-rays at beamline 13-ID-E at the Advanced Photon Source (APS), Argonne National Laboratory (Chicago, IL). Due to the penetrative nature of synchrotron-based analysis, thin sections were used for synchrotron-based analysis, instead of 1-cm epoxy pucks, to prevent the 
diffraction of X-rays from mineral phases deeper in the sample, in addition to the target grains. Xray fluorescence maps and XRD patterns were collected using an incident beam energy of 18.0

$291 \mathrm{keV}$ and a $2 \mu \mathrm{m}$ beam diameter. Two-dimensional, continuous $\mu-\mathrm{XRF} / \mathrm{XRD}$ mapping was 292 completed at frame rates of 50 to $100 \mathrm{~ms}$ per pixel. Specific points identified on $\mu$-XRF maps were 293 subsequently selected as targets for longer duration $\mu$-XRD measurements. The fluorescent 294 radiation was measured using a Hitachi 4-element Vortex ME4 silicon drift diode positioned at $29590^{\circ}$ to the incident beam and connected to a Xspress 3 digital X-ray multi-channel analyzer system. 296 X-ray diffraction was measured using a Perkin Elmer XRD1621 digital flat panel detector placed $297400 \mathrm{~mm}$ from the sample and operating in transmission mode. Post-hoc processing and analysis of $298 \mu$-XRF maps was performed using Larch software (Version 0.9.46; Newville, 2019). Micro-XRF 299 element maps included strontium (Sr) to identify and delineate detrital minerals (e.g., feldspars, 300 micas, and clay minerals) within the sediment. Dioptas software (Prescher and Prakapenka, 2015) 301 was used to calibrate and integrate XRD data; phase identification was performed in X'Pert 302 HighScore Plus.

\subsubsection{Bulk X-ray Absorption Near-Edge Structure (XANES)}

To determine the relative distribution of As oxidation states in the sediments, As K-edge

305 XANES data were collected at Sector 20-BM of the APS. Preparation of samples for these analyses

306 (Hambone Lake $n=3$; Powder Mag Lake $n=3$; Bulldog Lake $n=3$ ) followed procedures 307 described by Van Den Berghe et al. (2018). Standard materials were selected to cover the principal 308 oxidation states exhibited by As in lacustrine systems (-1 to +5; Supplemental data Table ST1). 309 Operational conditions and post-hoc data processing are detailed in Miller et al. (2020). The 310 distribution of oxidation states reported are component sums, normalized to $100 \%$. 


\section{$311 \quad 4.0 \quad$ Results}

\section{$312 \quad 4.1 \quad$ Sediment and porewater geochemistry}

Near-surface sediment As concentrations range from 80 to $1,010 \mathrm{mg} \cdot \mathrm{kg}^{-1}$ in the three lakes

314 sampled near Tundra Mine (Fig. 2). The highest solid-phase As concentrations were observed in

315 Bulldog Lake (median $=570 \mathrm{mg} \cdot \mathrm{kg}^{-1} ;$ range $=200$ to $1,010 \mathrm{mg} \cdot \mathrm{kg}^{-1} ; n=7$ ) with maximum values

316 occurring from 2 to $3 \mathrm{~cm}$ in the $37 \mathrm{~cm}$ deep sediment profile. Maximum dissolved As

317 concentrations in porewater were observed in Powder Mag Lake (maximum: $383 \mu \mathrm{g} \cdot \mathrm{L}^{-1}$ ) and are

318 an order of magnitude higher than those measured in Bulldog Lake (maximum $83 \mu \mathrm{g} \cdot \mathrm{L}^{-1}$ ). The

319 concentration and down-core distribution of redox-sensitive elements ( $\mathrm{Fe}$ and $\mathrm{S}$ ) varies between

320 the sediment cores collected from Bulldog and Powder Mag lakes (Fig. 2; Supplemental data

321 Tables ST2, ST3). Based on grab samples, near-surface sediment concentrations of As in Hambone

322 Lake ranged from 79.6 to $622 \mathrm{mg} \cdot \mathrm{kg}^{-1}(n=6$; Supplemental Data ST4).

Downcore profiles of porewater and sediment concentrations in Powder Mag and Bulldog

324 lakes range demonstrate that dissolved As concentrations range from 21 to $383 \mu \mathrm{g} \cdot \mathrm{L}^{-1}$ in the near-

325 surface sediment (Fig. 2; Supplemental data Tables ST5, ST6). In these two lakes, maximum

326 dissolved As concentrations in sediment occur at or just below the sediment-water interface (SWI;

327 Fig. 2). In Powder Mag Lake, maximum porewater As concentrations occur at the SWI, while in

328 Bulldog Lake peak concentrations are observed at $2.5 \mathrm{~cm}$ depth.

Concentration profiles of selected dissolved redox-sensitive species (As, Fe, S) are shown

330 in Fig. 2. In Bulldog Lake, porewater distribution of dissolved Fe is characterized by a sharp

331 subsurface concentration gradient in the shallow porewaters with the maximum concentration

$332\left(5.02 \mathrm{mg} \cdot \mathrm{L}^{-1}\right)$ occurring at the SWI. Conversely, from 0 to $5 \mathrm{~cm}$, dissolved $\mathrm{S}$ concentrations 
333 increased non-linearly and reach a subsurface maximum at $3.5 \mathrm{~cm}$ depth. Profiles of dissolved $\mathrm{Fe}$ 334 and S are notably different in Powder Mag Lake with minimal surface enrichment observed. circum-neutral, ranging from 5.7 to 7.5 (median $=5.8 ; n=11$; Supplemental Data ST5). The highest $\mathrm{pH}$ values are observed in Powder Mag Lake (range = 6.3 to 7.5; Supplemental Data ST6). Porewater data are not available for Hambone Lake; however, past environmental monitoring recorded surface water pH from 6.4 to 8.3 (AANDC, 2013; Golder Associates Ltd., 2016). This

340 range is similar to circum-neutral surface water $\mathrm{pH}$ values measured by the authors in 2016 for 341 Powder Mag $(\mathrm{pH}=7.01)$ and Bulldog lakes $(\mathrm{pH}=6.75)$.

(a) Powder Mag Lake

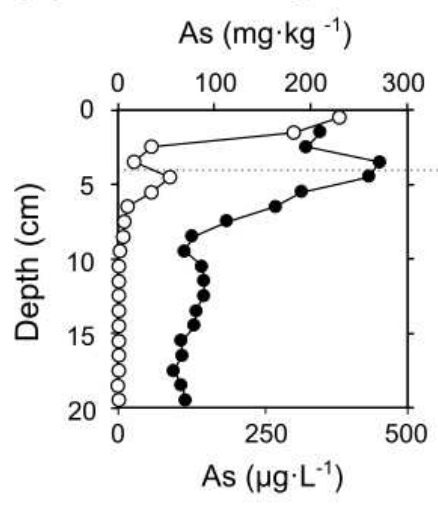

(b) Bulldog Lake

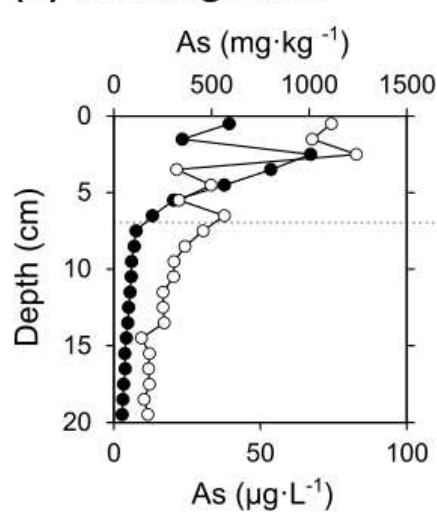

342
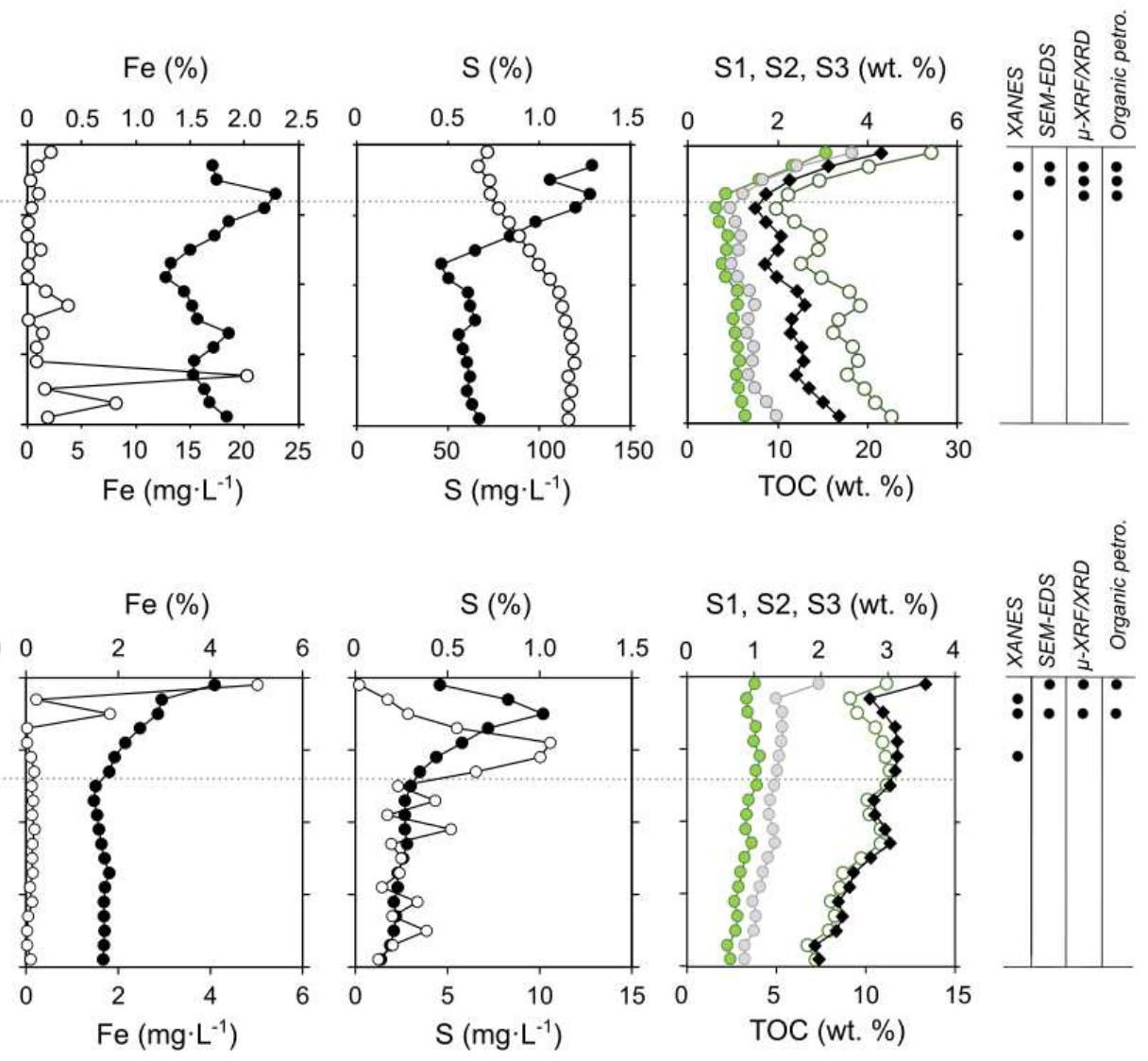

- Sediment O Porewater O S1 O S2 O S3 $\bullet$ TOC

Fig. 2. Downcore plots of As, Fe, and S concentrations in sediment and porewater, and solid-phase organic matter composition in the near-surface sediment of (a) Powder Mag Lake and (b) Bulldog Lake. Note the scale of the x- 
axes varies between each lake. The horizontal dotted line represents the onset of mining activities in 1964 (modified from Miller et al., 2019).

\subsection{Characterization of organic material in sediment}

Total organic carbon (TOC) content in the near-surface sediment of all lakes studied ranges from 8.7 to $21.5 \mathrm{wt} . \%$ (median $=11.4$ wt. $\% ; n=25$ ), with maximum concentrations observed at the SWI in Powder Mag Lake (Fig. 2; Supplemental data Tables ST2, ST3, ST4). In both Powder Mag and Bulldog lake sediment cores, the highest OM concentrations are observed at the SWI. The majority of labile OM (pyrolysable carbon) is composed of S2 (median $=2.4$ wt. \%; range $=$ 1.2 to 5.4 wt. \%; $n=25)$. In Hambone Lake, the highest TOC (15.5 wt. \%) and S2 (4.96 wt. \%) occur at the site farthest from the treated tailings effluent discharge location (HAM-2; Fig. 1).

Figure 3 juxtaposes fluorescence-light photomicrographs and SEM-BSE imagery of OMAs (A, B, E, F) and terrigenous OM (C, D) preserved in near-surface sediment of Powder Mag and Hambone lakes. Combining these analytical techniques demonstrates the heterogeneous nature of these particles and allows for the comparative and qualitative analysis of both the inorganic and organic components. Classification and identification of sediment $\mathrm{OM}$, based on optical properties (fluorescence and reflectance) and morphology indicate that $\mathrm{OM}$ in the nearsurface sediment of lakes in the Tundra Mine region is derived from both aquatic and terrestrial sources. Woody fragments and resin, suberin (i.e., roots and bark; Fig. 3D), cutinite (i.e., cuticle of leaves and stems) and funginite (Fig. 3C) from terrestrial vegetation are common in the nearsurface sediment. Aquatic-derived $\mathrm{OM}$ is also abundant and comprised primarily of alginate (benthic and planktonic; Fig. 3). Chlorophyllinite is derived from chlorophyll pigments and can be either aquatic or terrestrial in origin (Fig. 3E1). Organo-mineral aggregates (comprised of amorphous OM, particulate macerals (e.g., alginate, chlorophyllinite), oxidized amorphous OM 
369 (Fig. 3A1), and mineral matter) are abundant in all sediment samples studied (Fig. 3). Oxidation 370 of amorphous $\mathrm{OM}$ and terrigenous $\mathrm{OM}$ is commonly observed and results in a spectral shift 371 towards lower energy fluorescence wavelengths (i.e., redshift; Fig. 3). SEM-BSE imagery and 372 reflected fluorescence light microscopy show that sulphide and Fe-(oxide) mineral precipitates are 373 closely associated with oxidized aquatic and terrestrial-derived OM (Fig. 3). Unoxidized aquatic 374 and terrestrial-derived OM is identifiable in the sediment as it does not display a spectral shift and 375 preserves its characteristic fluorescence (Fig. 3). 

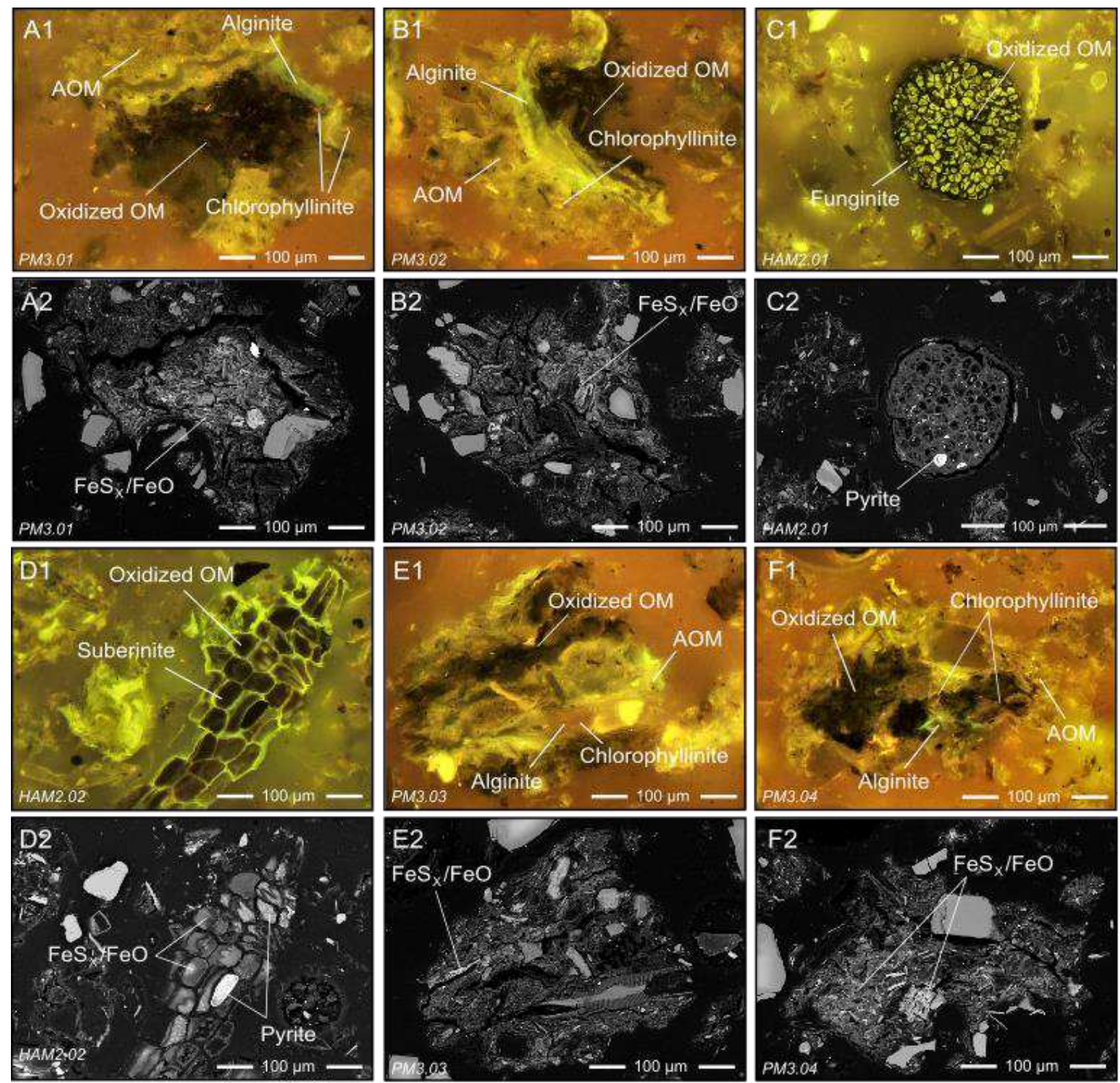

Fig 3. Paired (1) fluorescence-light photomicrographs under oil immersion and (2) SEM-BSE images of organoE1, F1; brown fluorescing), alginate (A1, B1. F1; green fluorescing), and amorphous $O M(A O M)(A 1, B 1, E 1, F 1$; green to yellow fluorescing). A = Powder Mag (grain PM3.01; $2-3 \mathrm{~cm}) ; B=$ Powder Mag (grain PM3.02; $2-3$

$\mathrm{cm}$ ); $C=$ Hambone Lake (grain HAM2.01; Sample 2); D = Hambone Lake (grain HAM2.02; Sample 2); E = Powder Mag (grain PM3.03; $2-3 \mathrm{~cm}) ; F=$ Powder Mag $($ grain PM3.04; $2-3 \mathrm{~cm})$. 


\subsection{Solid and aqueous As speciation}

nature and fine grain size suggest the EMPA results should be considered semi-quantitative.

\subsubsection{SEM-based Automated Mineralogy and Electron Microprobe analyses}

Fine grained aggregates of $\mathrm{Fe}$-sulphides and $\mathrm{Fe}-($ oxy $)$ hydroxides $\left(\mathrm{Fe} \mathrm{S}_{\mathrm{x}} / \mathrm{FeO}\right)$ are abundant in the near-surface sediment of all lakes studied and observed in association with both OMAs and terrigenous OM. SEM-based EDS mapping illustrates the precipitation of both Fe and $\mathrm{S}$ within these authigenic minerals (Fig. 4). Arsenic concentration associated with these authigenic minerals ranges from less than detection to $2.0 \mathrm{wt}$ \% (48 particles; 89 spots); however, the heterogeneous
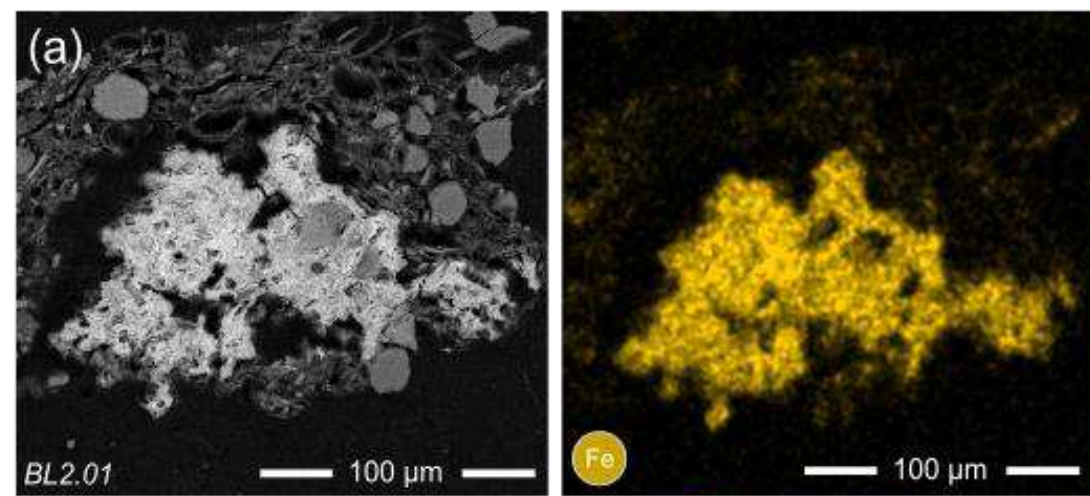

\section{(b)}
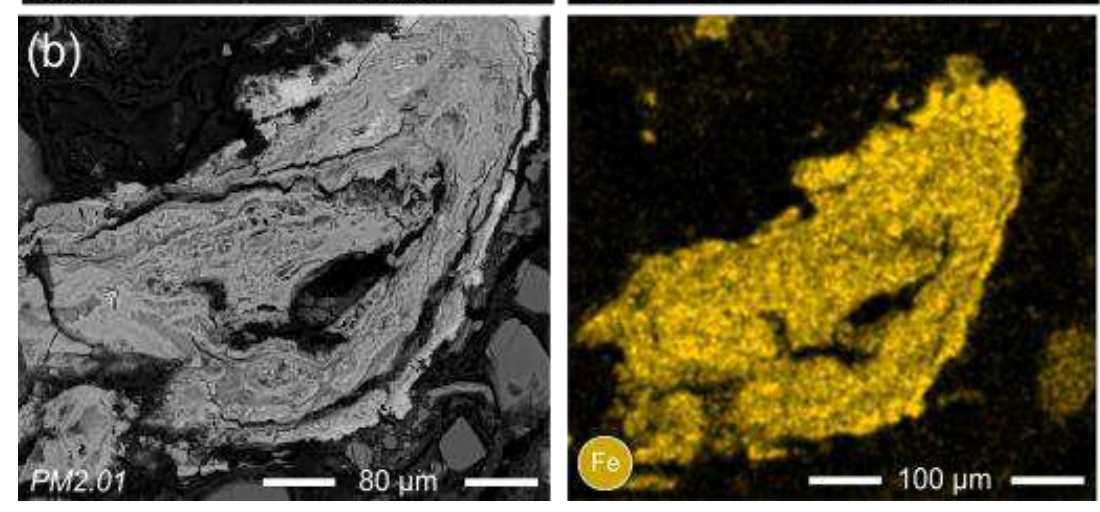

\subsubsection{Synchrotron-based $\mu-X R F$ and $\mu-X R D$}

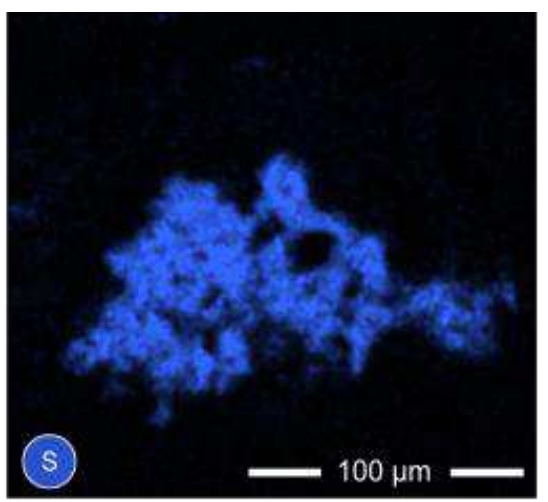

Fig. 4. SEM-BSE images and EDS element maps of (a) OMAs and (b) terrigenous OM preserved in the near-surface sediment of (a) Bulldog Lake (grain BL2.01; $1-2 \mathrm{~cm}$ ) and (b) Powder Mag Lake (grain PM2.01; $1-2 \mathrm{~cm}$ ).

Micro-XRF results confirm both the heterogeneous nature of OMAs and terrigenous OM, as well as the association of As with both types of OM (Fig. 5). Organo-mineral aggregates are 
comprised of both fine-grained detrital grains (i.e., silicates, phyllosilicates, quartz, hematite) and

400 mineral phases that may be authigenic in origin (i.e., ferrihydrite, feroxyhyte, goethite, maghemite,

401 mackinawite, pyrite; Fig. 6; Supplemental data Figure SF2). Terrigenous OM is associated with

402

goethite, ferrihydrite, maghemite, lepidocrocite, pyrite, and mackinawite (Fig. 6).

403

Synchrotron-based micro-XRF element maps demonstrate that As is physically associated

404

with terrigenous $\mathrm{OM}$ and OMAs (Fig. 5). Arsenic is generally observed with authigenic $\mathrm{FeS} / \mathrm{FeO}$

405

minerals and is dispersed throughout the Fe-bearing inorganic components associated with

406

terrigenous OM (Fig. 5a to d). In contrast, As in OMAs is instead more commonly observed either

407

as micron-sized grains within the organic material or dispersed throughout the amorphous OM

408

(Fig. 5e to h). Micro-XRD analyses of the OMAs suggest these micron-sized grains may be As-

409

bearing sulphide minerals, such as orpiment (As2 $\mathrm{S}_{3}$; Fig. 6a); however, $\mu$-XRD analysis results did

not provide identifiable diffraction patterns for many of these As-rich regions (Fig. 6).

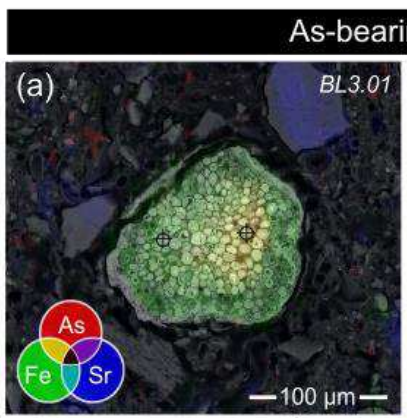

As-bearing TOM
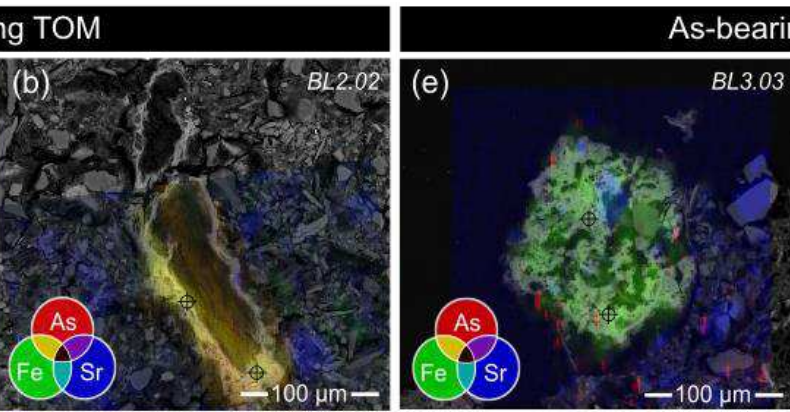

As-bearing OMAs
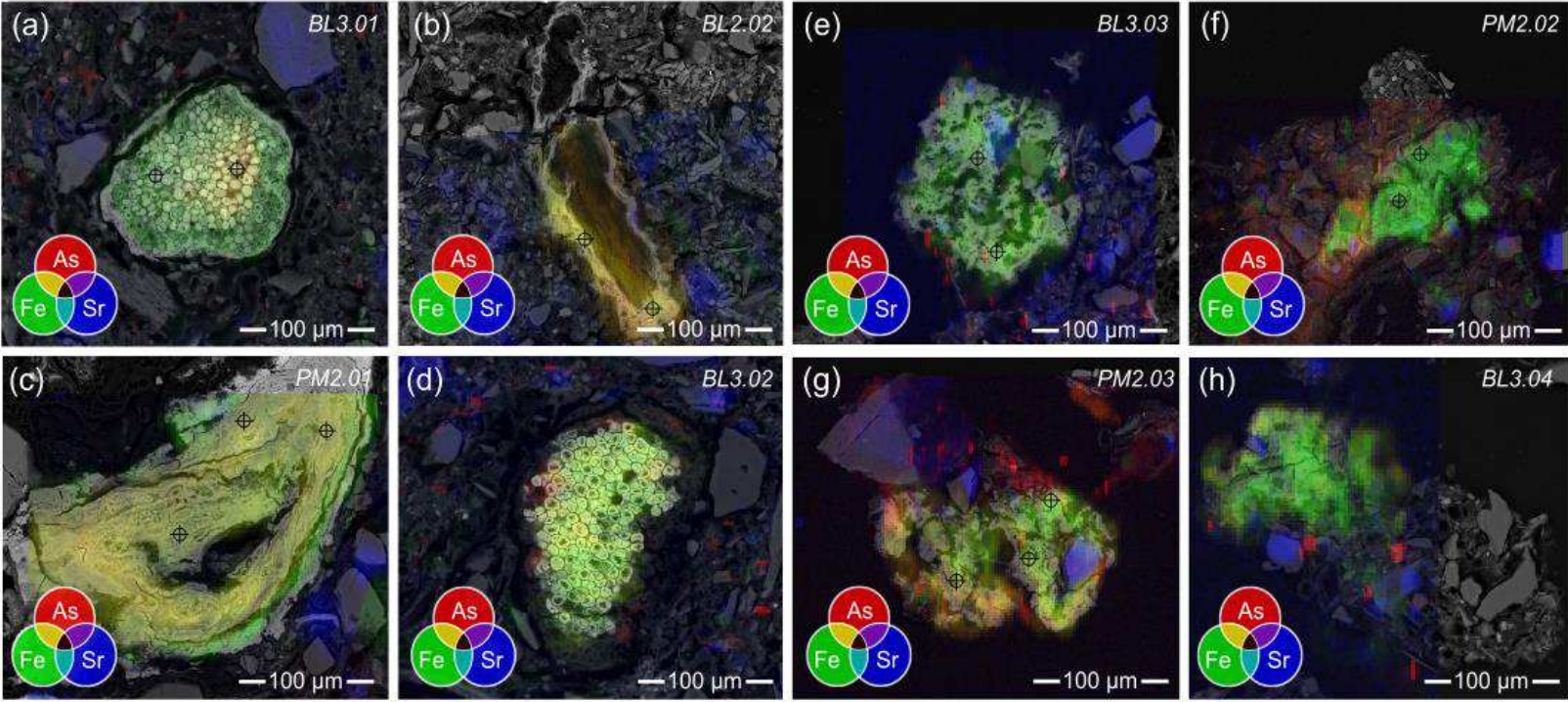

Fig. 5. Micro-XRF element maps showing As-Ka (red), Fe-Ka (green), and Sr-Ka (blue) intensities overlain on SEM-BSE images of As-bearing terrigenous $O M(a, b, c, d)$ and OMAs $(e, f, g, h)$. Colour intensities are not comparable between maps and are not intended to represent exact concentrations. Cross hairs demonstrate location of EPMA analysis, note that symbol is larger than beam diameter. A) Bulldog (grain BL3.01; $2-3 \mathrm{~cm}$ ); B) Bulldog (grain BL2.02; 1 - 2 cm); C) Powder Mag (PM2.01; $1-2 \mathrm{~cm}) ; D)$ Bulldog (BL3.02; 2 - $3 \mathrm{~cm}) ;$ E) Bulldog (grain 

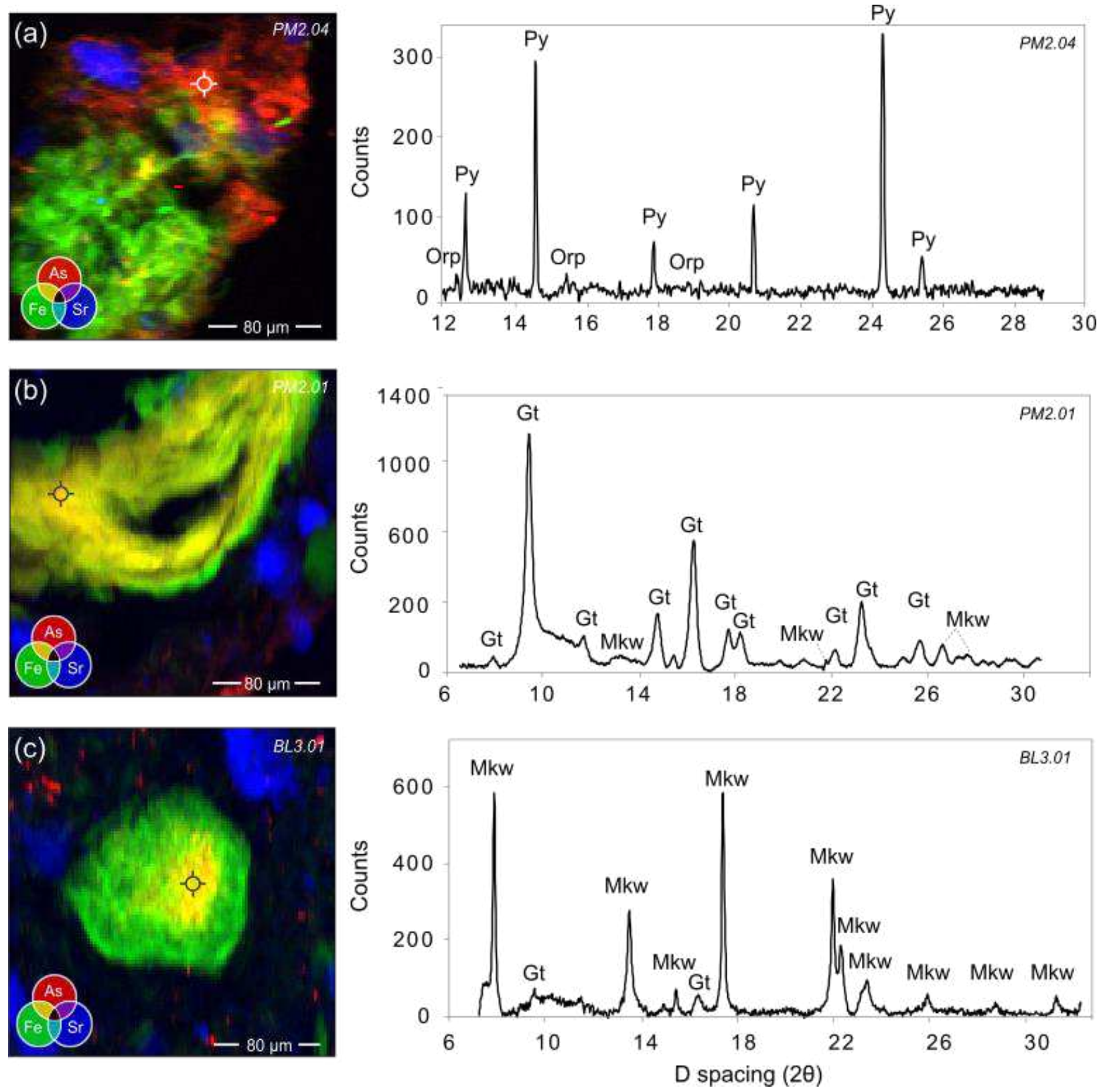

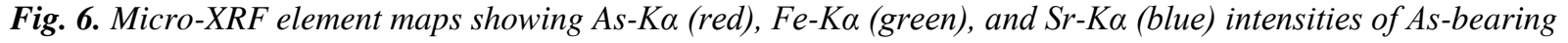
OMAs $(a)$ and terrigenous $O M(b, c)$. Colour intensities are not comparable between maps and are not intended to represent exact concentrations. Integration of the $\mu-X R D$ patterns shows the presence of discrete grains of pyrite (Py) and orpiment (Orp) associated with OMAs, which are comprised of a heterogenous mixture of detrital (not shown) and authigenic minerals (e.g., feroxyhyte (Feroxy)). Authigenic minerals associated with terrigenous OM are comprised of goethite $(\mathrm{Gt})$ and mackinawite (Mkw). Cross hairs demonstrate location of $\mu$-XRD analysis, note that symbol is larger than beam diameter. A = Powder Mag Lake (grain PM2.05; $1-2 \mathrm{~cm}$ ); B = Powder Mag (PM2.01; $1-2 \mathrm{~cm}) ; C=$ Bulldog (BUL3.01; $2-3 \mathrm{~cm})$. Additional analyses are provided in Supplemental Data. 
In near-surface $(0$ to $10 \mathrm{~cm}$ ) sediment porewaters of Powder Mag and Bulldog lakes, As

431 (V) is the predominant inorganic aqueous As species, except at the SWI $(0-1 \mathrm{~cm})$ in Bulldog Lake, 432 where As (III) is the dominant oxidation state (Fig. 7). Maximum dissolved As concentrations in 433 both lakes (Fig. 2) occur where As (V) proportions are highest and proportions of AsR are lowest 434 (Fig. 7). In Bulldog Lake, a trend of increasing proportions of As (V) with depth is observed, while 435 below a depth of $1 \mathrm{~cm}$, the relative proportion of As (III) is consistently around $10 \%$ of total 436 porewater As concentration. In Powder Mag Lake, no consistent down-core trend in the proportions of both As (III) and AsR is observed in near-surface porewaters.

The As K-edge XANES spectra demonstrate that reduced solid-phase As species (As (-I), As (III)) predominate in the near-surface sediment of all lakes studied, accounting for an average 440 of $80 \%(n=9)$ of total As (Fig. 7; Supplemental data Table ST7). In Powder Mag Lake, the 441 relative proportions of O-bound As (III) and As (V) species (11869.7 eV and $11873.2 \mathrm{eV}$, 442 respectively) are higher than S-coordinated As (-I) or As (III) (11867.0 and $11867.7 \mathrm{eV}$, 443 respectively). At the SWI, O-bound As (III) and As (V) account for $25 \%$ and $47 \%$ of total As, 444 respectively. An increase in S-bound As species is observed at $3.5 \mathrm{~cm}$ depth and corresponds to 445 maximum As concentrations $\left(271 \mathrm{mg} \mathrm{kg}^{-1}\right)$ in the near-surface sediment (Fig. 2A). Conversely, in 446 Bulldog Lake, S-coordinated As species account for approximately $40 \%$ of solid-phase As species 447 in the upper $3 \mathrm{~cm}$ of sediment. A trend of decreasing S-coordinated As species and increasing O448 bound As species is observed with depth in Bulldog Lake. In Hambone Lake, ratios of O- and S449 bound As species are similar in sediment close to the treated tailings effluent discharge location; 450 however, the relative proportions of S-bound species increase with distance toward the peatland at 451 the NE end of the lake that may be a source of S (Figs. 1, 7C). 

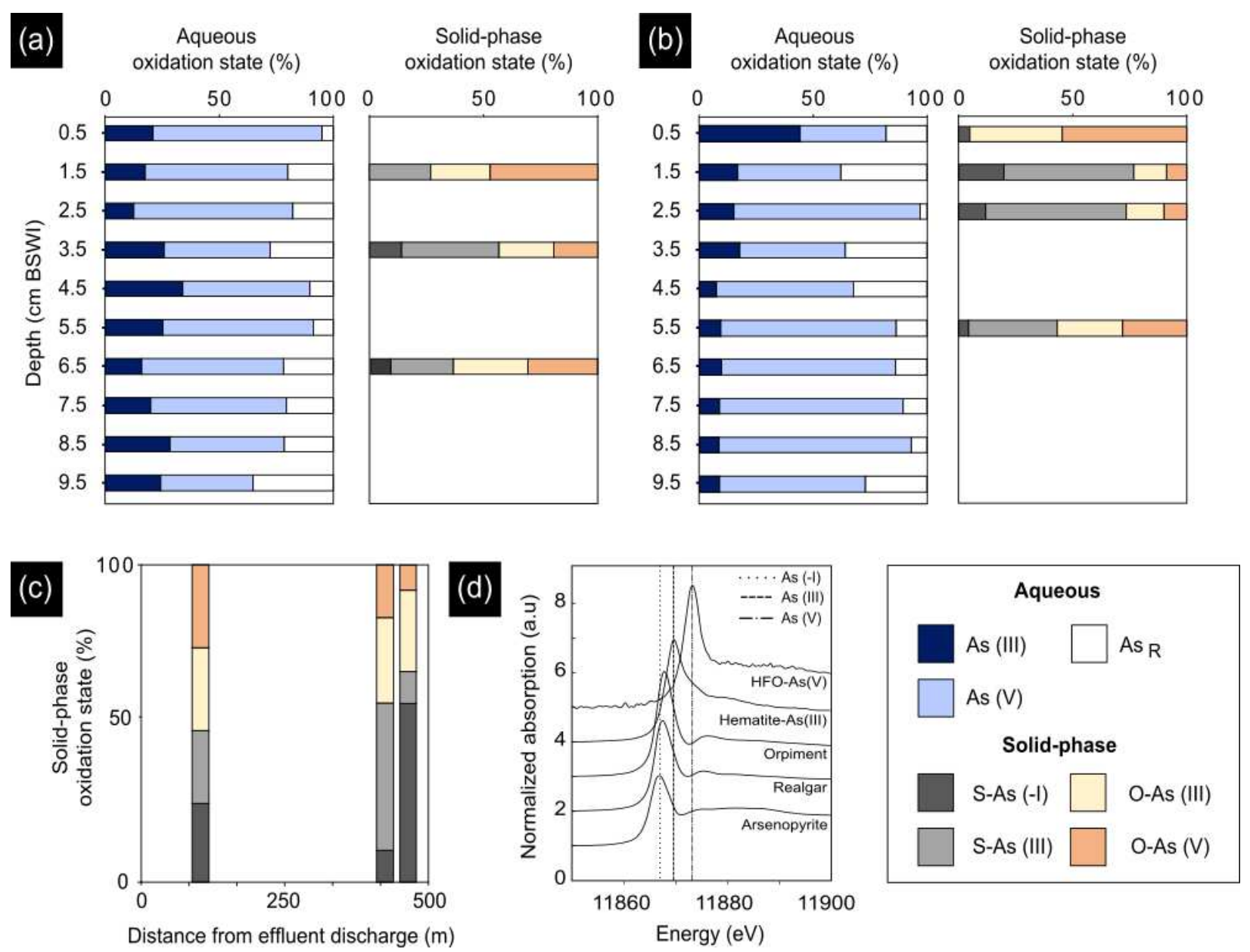

Distance from effluent discharge $(\mathrm{m})$

453

454

455

456

457

Fig. 7. Relative distribution of As species in porewater (HG-AFS) and sediment (bulk XANES) with depth in the (a) Powder Mag Lake and (b) Bulldog Lake sediment cores and (c) Hambone Lake with distance from the effluent discharge location in surface sediments (Fig. 1). XANES spectra of standards (d). Averaged XANES spectra and LCF fitting for samples is provided in Supplemental Data.

\subsection{Discussion}

\subsection{Sources of As and organic matter to lakes}

The primary mechanisms of inorganic As delivery to the near-surface sediment of Hambone, Powder Mag, and Bulldog lakes are related to legacy gold mining practices with a minor contribution from the weathering of mineralized bedrock (Miller et al., 2019). Arsenic may also be introduced to the lake sediments from the watershed in association with aquatic and terrestrialderived OM. Dissolved As may bioaccumulate in aquatic organisms living in the water column, such as phytoplankton and zooplankton, to concentrations orders of magnitude higher than those 
465 in ambient waters (Eisler, 1988; Hellweger et al., 2003; Lopez et al., 2017). Abundant labile OM

466 is observed both petrographically (alginate) and geochemically (S1 and S2) in the near-surface

467 sediment of Bulldog and Powder Mag lakes, suggesting that aquatic organisms are accumulating

468 As and delivering it to near-surface sediment (Fig. 2; Caumette et al., 2012). Previous studies have

469 shown that algal scavenging is an important mechanism for transporting $\mathrm{Hg}$ to the bottom

470 sediments in high Arctic lakes (Outridge et al., 2007, 2017; Stern et al., 2012); however, the

471 importance of this process is less certain in sub-Arctic lakes with more diverse sources of both

472 autochthonous and allochthonous OM. In surface waters, As may form aqueous and colloidal

473 complexes with OM and dissolved or suspended Fe (III) and eventually accumulate in the near-

474 surface sediment (Ritter et al., 2006; Sundman et al., 2014). The formation of these organo-ferric

475 complexes and their affinity for binding trace metals is influenced by seasonal fluctuations in

476 surface water physiochemistry (i.e., temperature, redox conditions, light penetration) and

477 microbiological metabolism (Shirokova et al., 2013; Palmer et al., 2019).

High dissolved organic carbon (DOC) and total Fe in both Powder Mag (DOC $=16.6 \mathrm{mg} \cdot \mathrm{L}^{-}$

$\left.479{ }^{1} ; \mathrm{Fe}=0.39 \mathrm{mg} \cdot \mathrm{L}^{-1}\right)$ and Hambone $\left(\mathrm{DOC}=16 \mathrm{mg} \cdot \mathrm{L}^{-1} ; \mathrm{Fe}=0.55 \mathrm{mg} \cdot \mathrm{L}^{-1}\right)$ surface waters, reported 480 by INAC (2005) and Miller et al. (2019), suggest that the formation of complexes between 481 arsenate, suspended Fe-(oxy)hydroxide colloids, and OM, play a significant role in the transport 482 of both As and OM to the bottom sediments (Ritter et al., 2006; Golder Associates Ltd., 2016). 483 Additionally, petrographic evidence of terrigenous OM (i.e., cutinite, funginite, and sporinite) and 484 the presence of detrital As-bearing minerals demonstrate that the watershed is contributing both $485 \mathrm{OM}$ and As to these lake systems (Fig. 3). 


\subsection{OMAs and As sequestration}

Organo-mineral aggregates, comprised of amorphous OM, particulate macerals (e.g., sporinite and alginate), and both authigenic and detrital minerals, are common in the near-surface sediment of the lakes studied near Tundra Mine (Fig. 4). In these aggregates, mixtures of detrital minerals (i.e., silicates, quartz, pyrrhotite) and fine-grained authigenic mineral phases (i.e., ferrihydrite, goethite, maghemite, mackinawite, pyrite) occur together with amorphous OM (Fig.

3). Arsenic is associated with these aggregates as: (1) discrete clusters, (2) evenly dispersed within the amorphous OM matrix, and (3) sorbed to and/or co-precipitated with authigenic $\mathrm{FeS} \times \mathrm{FeO}$ portions of the grain (Figs. 5, 6).

Arsenic-bearing OMAs are present at and below the SWI in both Bulldog and Powder Mag lakes where redox conditions progressively change from oxic to anoxic. This transition in redox conditions is evident in the aqueous speciation of As and porewater profiles of dissolved Fe, As, and $\mathrm{S}$ concentrations. A shift in aqueous As speciation from mainly As (V) in overlying waters (Powder Mag Lake: $78 \%$ As (V); Bulldog Lake: $95 \%$ As (V)) to increasing proportions of As (III) in the near-surface sediment occurs in both lakes (Miller et al., 2019; Fig 7). Elevated concentrations of dissolved $\mathrm{Fe}$ and As in the shallow porewaters and increasing concentrations of

502 dissolved S with depth in the sediment of both lakes (Fig. 2) also indicates the onset of reductive processes in the near-surface sediments, as described in the study by Martin and Pedersen (2002). Solid-phase speciation and mineralogy also provides evidence of the progressive onset of reducing conditions, with a shift from O-bound As (V) species at the SWI to S-coordinated As (-I) or As (III) at $\sim 3 \mathrm{~cm}$ in both lakes (Fig. 7). 
XANES, which indicates that S-coordinated As (III) accounts for approximately $60 \%$ of solidphase As in the near-surface sediment of Bulldog Lake. A shift in fluorescence colour (from green to red wavelengths) is observed in the amorphous $\mathrm{OM}$ associated with these aggregates. This

512 fluorescence shift is caused by the oxidation of $\mathrm{OM}$ as it acts as an electron donor to drive sulphide 513 mineralization, suggesting that these discrete As minerals are forming in situ (Fig. 3; Davis et al., 514 1990) and that OM is promoting the formation of As-bearing sulphide minerals, possibly as a 515 substrate for microbial growth (Galloway et al., 2018). These grain-scale observations suggest that 516 redox conditions are likely to be heterogeneous at a given depth in the near-surface sediments, and 517 will depend in part of the spatial distribution of particulate OM. The role of reactive OM in the 518 precipitation of authigenic As-bearing minerals has previously been demonstrated in both 519 laboratory (Kirk et al., 2004, 2010) and field-based sediment studies (e.g., Langner et al., 2011; 520 Galloway et al., 2018; Wang et al., 2018; Miller et al., 2020).

Within OMAs, coupled $\mu$-XRF and fluorescence microscopy analyses demonstrate that As 522 is dispersed throughout the amorphous OM (Fig. 5). These regions of elevated As concentrations 523 did not diffract, suggesting that As may be bound to OM through the formation of ternary 524 complexes with Fe ions and/or bonding with hydroxyl groups (Caumette et al., 2012; Biswas et 525 al., 2019). The results of this study suggest that O-bound As in the near-surface sediment of 526 Bulldog, Hambone, and Powder Mag lakes is attributed to sorption to and/or co-precipitation with 527 Fe-(oxy)hydroxides. In addition, this study demonstrates that the association of As with OMAs 528 may contribute to the abundance of O-bound As species, particularly below the SWI where Fe529 (oxy)hydroxides would begin to reductively dissolve (Fig. 7). Less commonly, As is observed co-precipitated with or sorbed to authigenic Fe531 (oxy)hydroxide and Fe-sulphide minerals within the OMAs (Fig. 5). Regions of authigenic 
532 mineralization with higher proportions of As are most commonly comprised of a mixture of

533 ferrihydrite and goethite (Fig. 6). At mildly acidic to circumneutral pH, As (III) and As (V) have

534 similar affinities for Fe-(oxy)hydroxides, suggesting that As is associated with these phases

535 through sorption. This may explain the presence of both As valence states in the near-surface

536 sediment of all three lakes studied (Fig. 7; Dixit and Hering, 2003). Mackinawite mineralization

537 is also observed within these OMAs and, based on uXRF maps, trace amount of As have been

538 observed to co-precipitate or sorb to this phase (Fig 5). However, As is more commonly observed

539 as fine-grained As-sulphides. These observations support the laboratory-based studies conducted

540 by Wolthers et al. (2005) who observed the formation of poorly crystalline $\mathrm{As}_{2} \mathrm{~S}_{3}$ precipitates at

541 the surface of FeS minerals at neutral $\mathrm{pH}$.

\section{$542 \quad 5.3 \quad$ Arsenic sequestration with terrigenous OM}

Arsenic-bearing terrigenous $\mathrm{OM}$ is observed in the near-surface sediment of all lakes

544 studied. Ranging in size from 20 to $200 \mu \mathrm{m}$, these organic macerals are primarily derived from

545 terrestrial vegetation (i.e., roots, leaves, spores; Figs. 3, 4). The modern landscape of the Tundra

546 Mine region consists of tundra shrubland with stunted spruce and fir, and organic-rich depressions,

547 indicating terrestrial weathering is a source of OM to these lakes (Ecosystem Classification Group,

$5482008 ; 2012)$. The organic structure of these macerals contains mixtures of authigenic mineral

549 precipitates, including goethite, ferrihydrite, maghemite, lepidocrocite, pyrite, and mackinawite

550 (Fig. 6; Supplemental data Figure SF1). The heterogenous nature of these grains, comprised of

551 both sulfide and oxide precipitates, suggests that they formed at an oxic-to-anoxic transition zone

552 in the sediment column.

The association between organic carbon in sediments and reactive Fe phases has been

554 found to play a significant role in the stabilization of OM under dynamic redox conditions. These 
recent studies suggest that the interactions between Fe and organic compounds, such as those derived from vascular plants, stabilize both authigenic Fe minerals and OM as conditions become moderately reducing at redox-interfaces (Lalonde et al., 2012; Riedel et al., 2013; Chen et al., 2015). This has important implications for shallow lake sediments where both authigenic Feminerals and terrigenous OM act as potential sorbents and influence the mobility of As and other elements.

Combined $\mu$-XRD and EPMA analyses demonstrate that authigenic Fe-(oxy)hydroxide and/or Fe-sulphide minerals associated with terrigenous OM commonly contain more than 1 wt. $\%$ As (Fig. 4). Micro-XRF analysis shows that As is concentrated at the centre of these grains and decreases outwards; however, within a terrigenous OM maceral, no consistent patterns were observed in either the distribution of authigenic minerals or the association of As with these phases (Fig. 5). Recent research investigating the immobilization of metal(loid)s under transitional redox conditions suggests that the timing of authigenic mineral $\left(e . g ., \mathrm{FeS}_{\mathrm{x}}\right)$ precipitation influences the effectiveness of this process in contaminant removal via sequestration in sediments (Vega et al., 2017; Du et al., 2018). For example, scavenging of dissolved As is more effective in systems where As co-precipitates with $\mathrm{FeS}$ in comparison to in settings where FeS forms in the sediment prior to introduction of the contaminant (Vega et al., 2017). The high As concentrations observed in Fesulphide minerals associated with terrigenous OM in lakes near Tundra Mine suggest that these sulphides precipitated authigenically in the mining-impacted lake sediments, sequestering dissolved As during their formation. Additionally, the co-precipitation of $\mathrm{OM}$ with $\mathrm{Fe}-$ (oxy)hydroxides can alter their affinity for metal sorption at mid- to low pH (Du et al., 2018). The results of this study suggest that while the influx of terrigenous OM is likely to result in As release from minerals to pore waters by enhancing reductive dissolution, it may also reduce the flux of 
578 dissolved As to overlying surface waters by facilitating the precipitation of authigenic Fe-

579 (oxy)hydroxide and $\mathrm{FeS}_{\mathrm{x}}$ minerals under changing redox conditions.

\subsection{Implications for long-term environmental monitoring}

The results of this study help to improve knowledge about the long-term fate of As in lake systems when increased autochthonous OM production and terrigenous (i.e., allochthonous) OM delivery promotes a shift from oxidizing to reducing conditions in the near-surface sediments and overlying waters. The degradation of accumulated labile OM will increase sediment oxygen demand, driving the progressive onset of reducing conditions and influence the stability of redoxsensitive elements (e.g., Fe, S, As) and minerals (e.g., Fe-oxides and sulphides). Changing redox conditions and shallowing of the sediment redoxcline are expected to release As to pore waters and overlying surface waters via reductive dissolution of Fe-(oxy)hydroxides or the oxidation of sulphides (e.g., Martin and Pedersen, 2002; Galloway et al., 2018; Schuh et al., 2019). However, this study demonstrates that solid-phase OM may also promote the sequestration of As at this transitional redox boundary by facilitating the formation of fine-grained As-sulphides, the precipitation of authigenic As-bearing $\mathrm{FeS}_{\mathrm{x}} / \mathrm{FeO}$ minerals, and the direct sorption of As to amorphous OM functional groups. As a result, the diffusion of As into porewaters may be abated by the presence of solid-phase OM in near-surface sediment. The net effect of these competing processes is difficult to predict as the present-day mineral hosts for As vary between lakes, which, in turn, will influence their long-term stability under changing redox conditions (Miller et al., 2019, 2020; Palmer et al., 2019).

Based on the results of this study, it is expected that increased concentrations of aquaticand terrestrially-derived labile OM will drive the redistribution of As in shallow lake sediments resulting in surface-enrichment of As. This will pose a challenge for interpretation of long-term 
monitoring data and may make it difficult to distinguish between mining impacts and the influence of current warming in the sub-Arctic. It is important that the influence of natural, climate-driven biogeochemical processes on the post-depositional mobility of As is considered within monitoring

604 programs aiming to delineate potential mining impacts.

\subsection{Limitations and Future Work}

Sorption and co-precipitation mechanisms are controlled by the biogeochemical conditions of near-surface lake sediments. Differences in the total metal(loid) concentrations, $\mathrm{pH}$, TOC, and OM composition of Hambone, Powder Mag, and Bulldog lake sediments will influence the effectiveness of solid-phase OM in the sequestration of As. The limited sample size of this study does not allow for broad predictions about how other sub-Arctic lakes might behave. This investigation does, however, demonstrate that solid-phase OM plays an important role in the cycling of As in near-surface sediment, and highlights the need for further study to determine the influence of seasonality, intra- and inter-lake variances, and reaction mechanisms between As (III), As (V) and solid-phase OM. While combining organic petrography techniques (Rock Eval, fluorescence microscopy) with geochemical speciation methods (SEM-based automated mineralogy, EPMA, synchrotron-based $\mu$-XRF/XRD) revealed novel observations, the sample preparation for each of these methods limits the ability of sequential analysis on individual grains. For example, 1-cm epoxy pucks are preferred to thin sections for fluorescence microscopy as the transmission of reflected light through a thin section may interfere with the OM fluorescence spectra. Conversely, for $\mu-\mathrm{XRD}$, thin sections are preferred to minimize the number of particles diffracting during analysis. Additionally, this study suggests that prolonged electron beam exposure on $\mathrm{OM}$ in unconsolidated sediment may result in thermal alteration and influence fluorescence microscopy interpretations. As a result, optimization of a method that allows grains 
624 to be analyzed sequentially would provide further evidence for the relationship between solid-

625 phase OM, authigenic minerals, and the cycling of elements of concern.

626

627

628

629

630

631

632

633

634

635

636

637

638

639

640

641

642

643

644

645

\subsection{Conclusions}

The association between As and solid-phase OM was examined to determine the influence of increased flux of aquatic- and terrigenous-derived OM on the long-term mobility of As in three mining-impacted lakes of the Tundra Mine region. Detailed geochemical and organic petrological analyses suggest that increased aquatic production in lakes and weathering of terrestrial vegetation near this former gold mine are impacting the mobility of legacy contaminants. While increased loading of labile OM will change redox conditions in lake sediments, driving the release of As to porewaters via reductive dissolution of As-bearing Fe oxyhydroxides, solid-phase OM may provide an additional substrate for As sequestration and promote the precipitation of As-bearing minerals under changing redox conditions at the SWI.

Increased aquatic-derived OM, interpreted to be a result of seasonal fluctuations and climate warming, was observed in the near-surface sediment of all lakes studied. Clumping and/or binding together of mineral matter and aquatic-derived OM formed OMAs, comprised of amorphous OM, particulate macerals (e.g., sporinite, alginate) and both authigenic and detrital mineral matter. Arsenic is associated with these phases, primarily in the form of authigenic, finegrained, poorly crystalline, As-sulphides (e.g., orpiment). Within these OMAs, As is also associated with amorphous $\mathrm{OM}$ and, to a lesser extent, with authigenic $\mathrm{FeS}_{\mathrm{x}} / \mathrm{FeO}$ precipitates (i.e., pyrite, goethite, ferrihydrite, mackinawite).

Increased input of terrigenous OM to the near-surface sediment of these mining-impacted lakes may facilitate the precipitation of reactive authigenic $\mathrm{FeS} / \mathrm{FeO}$ minerals, (e.g., lepidocrocite, 
646 ferrihydrite, goethite, mackinawite, pyrite) providing a substrate for As sequestration. The

647 presence of these As-bearing substrates at and below the SWI suggests that terrigenous-derived

$648 \mathrm{OM}$ in lake sediments plays a role in stabilizing redox-sensitive authigenic minerals (sulphides

649 and $\mathrm{Fe}-(\mathrm{oxy})$ hydroxides), and associated As, as redox conditions progressively change from oxic

650 to anoxic.

651 Through combined microscale geochemical and OM speciation analysis, this study

652 demonstrates that under dynamic redox conditions increased algal and terrestrially-derived OM

653 will mediate the flux of As to overlying surface water by: (1) facilitating the precipitation of

654 authigenic sulphides, (2) enhancing the stability of authigenic oxides, and/or (3) allowing for the

655 direct sequestration of As to OM. These findings provide strong evidence that solid-phase OM

656 plays an important role in the sequestration of As under changing redox conditions and results

657 demonstrate that changes in sediment redox conditions as a result of climate warming will affect

658 the mobility and fate of As in northern lakes. This study improves knowledge about As mobility

659 in lake sediments and can help to improve long-term monitoring strategies for As and other trace

660 metal(loid)s (e.g., $\mathrm{Cd}, \mathrm{Pb}, \mathrm{Sb}, \mathrm{Zn})$ that are affected by redox conditions. Based on the results of

661 this study, it is expected that increased concentrations of aquatic and terrigenous OM will result in

662 enrichment of As in near-surface lake sediments, making it more challenging to differentiate

663 mining impacts from those associated with current and forecasted warming trends in the sub-

664 Arctic.

665

666 


\section{8.0 Declaration}

$668 \quad$ Funding

669 This project was jointly funded by Polar Knowledge Canada (Project\# 1519-149, to JMG and RTP

670 (Carleton University)), the Environmental Geoscience Program, Natural Resources Canada (Metal

671 Mining Project, MBP; Northern Baselines Activity, JMG), a Natural Sciences and Engineering

672 Research Council of Canada (NSERC) Discovery Grant (HEJ; RGPIN/03736-2016), a NSERC

673 Northern Research Supplement (HEJ; RGPNS/305500-2016), the NSERC Create Mine of

674 Knowledge (CBM, Principle Investigator: Marc Amyot, Université de Montréal) and the Northern

675 Scientific Training programs (CBM, Project \# 306001).

676 Conflicts of interest/Competing interests

677 The authors declare that they have no known competing financial interests or personal

678 relationships that could have appeared to influence the work reported in this paper.

\section{Availability of data and material}

680 The primary data associated with this manuscript have been included as Supplementary Material.

681 Supporting data and further information on methods and materials are part of a Ph.D. thesis by the 682 lead author and are available at http://hdl.handle.net/1974/27588

683 Code availability

684 Not applicable

685

686

687 


\subsection{References}

AANDC, 2013. Water Balance Monitoring at the Tundra Mine Site: 2012 Update.

ACIA, 2005. Arctic Climate Impact Assessment. ACIA Overview report. Cambridge University Press. 1020 pp.

AECOM, 2015. Tundra Mine, NWT Remediation Environmental Monitoring Program: Water Quality Part L: 2014 and Historical Results

AECOM, 2018. Tundra Mine Adaptive Management Plan. Available from: http://registry.mvlwb.ca/Documents/MV2016L8-0003/MV2016L8-0003\%20-\%20INACCARD\%20-\%20Tundra\%20-\%20Adaptive\%20Management\%20Plan\%20-\%20Mar818.pdf

Albrecht, R., Sebag, D., Verrecchia, E., 2015. Organic matter decomposition: bridging the gap between Rock-Eval pyrolysis and chemical characterization (CPMAS13C NMR). Biogeochemistry 122, 101-111. https://doi.org/10.1007/s10533-014-0033-8

An, X., Huang, F., Ren, H., Wang, Y., Chen, Y., Liu, Z., Zhang, H., Han, X., 2017. Oxidative dissolution of amorphous FeS and speciation of secondary Fe minerals: Effects of $\mathrm{pH}$ and As (III) concentration. Chem. Geol. 462, 44-54. https://doi.org/10.1016/j.chemgeo.2017.04.025

Anawar, H., Tareq, S.M., Ahmed, G., 2013. Is organic matter a source or redox driver or both for arsenic release in groundwater? Phys. Chem. Earth 60, 49-56. https://doi.org/https://doi.org/10.1016/j.pce.2013.04.009

Andrade, C.F., Jamieson, H.E., Kyser, T.K., Praharaj, T., Fortin, D., 2010. Biogeochemical redox cycling of arsenic in mine-impacted lake sediments and co-existing pore waters near Giant Mine, Yellowknife Bay, Canada. Appl. Geochemistry 25, 199-211. https://doi.org/10.1016/j.apgeochem.2009.11.005

Barrett, P.M., Hull, E.A., Burkart, K., Hargrave, O., McLean, J., Taylor, V.F., Jackson, B.P., Gawel, J.E., Neumann, R.B., 2019. Contrasting arsenic cycling in strongly and weakly stratified contaminated lakes: Evidence for temperature control on sediment-water arsenic fluxes. Limnol. Oceanogr. 64, 1333-1346. https://doi.org/10.1002/lno.11119

Bauer, M., Blodau, C., 2006. Mobilization of arsenic by dissolved organic matter from iron oxides, soils and sediments. Sci. Total Environ. 354, 179-190. https://doi.org/10.1016/j.scitotenv.2005.01.027

Bennett, W.W., Teasdale, P.R., Panther, J.G., Welsh, D.T., Zhao, H., Jolley, D.F., 2012. Investigating arsenic speciation and mobilization in sediments with DGT and DET: A mesocosm evaluation of oxic-anoxic transitions. Environ. Sci. Technol. 46, 3981-3989. https://doi.org/10.1021/es204484k

Biswas, A., Besold, J., Sjostedt, C., Gustafsson, J.P., Scheinost, A.C., Planer-Friedrich, B., 2019. Complexation of arsenite, arsenate, and monothioarsenate with oxygen-containing 
functional groups of natural organic matter: An XAS Study. Environ. Sci. Technol. acs.est.9b03020. https://doi.org/10.1021/acs.est.9b03020

Blais, J.M., Kalff, J., 1995. The influence of lake morphometry on sediment focusing. Limnol. Oceanogr. 40, 582-588. https://doi.org/10.4319/lo.1995.40.3.0582

Bostick, B.C., Fendorf, S., Brown Jr., G.E., 2005. In situ analysis of thioarsenite complexes in neutral to alkaline arsenic sulphide solutions. Mineral. Mag. 69, 781-795. https://doi.org/10.1180/0026461056950288

Bright, D.A., Coedy, B., Dushenko, W.T., Reimer, K.J., 1994. Arsenic transport in a watershed receiving gold mine effluent near Yellowknife, Northwest Territories, Canada. Sci. Total Environ. 155, 237-252. https://doi.org/10.1016/0048-9697(94)90503-7

Bright, D.A., Dodd, M., Reimer, K.J., 1996. Arsenic in subarctic lakes influenced by gold mine effluent: the occurrence of organoarsenicals and 'hidden' arsenic. Sci. Total Environ. 180, 165-182. https://doi.org/10.1016/0048-9697(95)04940-1

Buckwalter-Davis, M., 2013. Automated Mineral Analysis of Mine Waste. MSc. Thesis. Queen's University. https://qspace.library.queensu.ca/bitstream/handle/1974/8200/BuckwalterDavis_Martha_J_201308_MSc.pdf?sequence=1\&isAllowed=y

Caumette, G., Koch, I., Moriarty, M., Reimer, K.J., 2012. Arsenic distribution and speciation in Daphnia pulex. Sci. Total Environ. 432, 243-250. https://doi.org/10.1016/j.scitotenv.2012.05.050

Carrie, J., Sanei, H., Stern, G., 2012. Standardisation of Rock-Eval pyrolysis for the analysis of recent sediments and soils. Org. Geochem. 46, 38-53. https://doi.org/10.1016/j.orggeochem.2012.01.011

CCME, 2001a. Canadian Sediment Quality Guidelines for the Protection of Aquatic Life, Environmental Protection.

CCME, 2001b. Canadian Water Quality Guidelines for the Protection of Aquatic Life Water Quality Index 1.0 Technical Report.

Chen, C., Dynes, J.J., Wang, J., Sparks, D.L., 2014. Properties of Fe-Organic Matter Associations via Coprecipitation versus Adsorption. Environ.Sci. Technol. 48, 13751-13759. https://doi.org/10.1021/es503669u

Chen, C., Kukkadapu, R., Sparks, D.L., 2015. Influence of Coprecipitated Organic Matter on $\mathrm{Fe} 2+$-catalyzed transformations of ferrihydrite: Implications for carbon dynamics. Enviromental Sci. Technlogy 49, 10927-10936. https://doi.org/10.1021/acs.est.5b02448

Couture, R.M., Van Cappellen, P., 2011. Reassessing the role of sulfur geochemistry on arsenic speciation in reducing environments. J. Hazard. Mater. 189, 647-652. https://doi.org/10.1016/j.jhazmat.2011.02.029

Crann, C.A., Patterson, R.T., Macumber, A.L., Galloway, J.M., Roe, H.M., Blaauw, M., Swindles, G.T., Falck, H., 2015. Sediment accumulation rates in subarctic lakes: Insights 
into age-depth modeling from 22 dated lake records from the Northwest Territories, Canada. Quat. Geochronol. 27, 131-144. https://doi.org/10.1016/j.quageo.2015.02.001

Craw, D., Bowell, R.J., 2014. The Characterization of Arsenic in Mine Waste. Rev. Mineral. Geochemistry 79, 473-505. https://doi.org/https://doi.org/10.2138/rmg.2014.79.10

Davis A., Rathbone R. F., Lin R. and Quick J. C., 1990. Observations concerning the nature of maceral fluoresence alteration with time. In Advances in Organic Geochemistry 1989 (Edited by Durand B. and Brhar F.). Org. Geochem. 16, 897-906. Pergamon Press, Oxford

DeSisto, S.L., Jamieson, H.E., Parsons, M.B., 2011. Influence of hardpan layers on arsenic mobility in historical gold mine tailings. Appl. Geochemistry 26, 2004-2018. https://doi.org/10.1016/j.apgeochem.2011.06.030

Dixit, S., Hering, J.G., 2003. Comparison of arsenic (V) and arsenic (III) sorption onto iron oxide minerals: implications for arsenic mobility. Environ. Sci. Technol. 37, 4182-4189. https://doi.org/10.1021/es030309t

Du, H., Peacock, C.L., Chen, W., Huang, Q., 2018. Binding of Cd by ferrihydrite organo-mineral composites: Implications for $\mathrm{Cd}$ mobility and fate in natural and contaminated environments. Chemosphere 207, 404-412. https://doi.org/10.1016/j.chemosphere.2018.05.092

Ecosystem Classification Group. 2008. Ecological Regions of the Northwest Territories - Taiga Shield. Department of Environment and Natural Resources, Government of the Northwest Territories, Yellowknife, NT. viii + 146 pp. + insert map

Ecosystem Classification Group. 2012. Ecological Regions of the Northwest Territories Southern Arctic. Department of Environment and Natural Resources, Government of the Northwest Territories, Yellowknife, NT. x + 170 pp. + insert map

Eisler, R., 1988. Arsenic hazards to fish, wildlife, and invertebrates: a synoptic review. Contam. Hazard Rev. 85, 1-65.

Fandrich, R., Gu, Y., Burrows, D., Moeller, K., 2007. Modern SEM-based mineral liberation analysis. Int. J. Miner. Process. 84, 310-320. https://doi.org/10.1016/j.minpro.2006.07.018.

Farquhar, M.L., Livens, F.R., 2002. Mechanisms of Arsenic Uptake from Aqueous Solution by Interaction with Goethite, Lepidocrocite, Mackinawite, and Pyrite: An X-ray Absorption Spectroscopy Study. Environ. Sci. Technol. 1757-1762. https://doi.org/10.1021/es010216g

Frey, K.E., McClelland, J.W., 2009. Impacts of permafrost degradation on arctic river biochemistry. J. Glaciol. 23, 169-182. https://doi.org/10.1002/hyp

Galloway, J.M., Sanei, H., Patterson, R.T., Mosstajiri, T., Hadlari, T., Falck, H., 2012. Total arsenic concentrations of lake sediments near the City of Yellowknife, Northwest Territories. Geological Survey of Canada Open File 7037, 1-47 
Galloway, J.M., Palmer, M., Jamieson, H.E., Patterson, R.T., Nasser, N., Falck, H., Macumber, A.L., Goldsmith, S.A., Sanei, H., Normandeau, P., Hadlari, T., Roe, H.M., Neville, L.A., and Lemay, D., 2015. Geochemistry of lakes across ecozones in the Northwest Territories and implications for the distribution of arsenic in the Yellowknife region. Part 1: Sediments; Geological Survey of Canada, Open File 7908, 1 .zip file. doi:10.4095/296954

Galloway, J.M., Swindles, G.T., Jamieson, H.E., Palmer, M., Parsons, M.B., Sanei, H., Macumber, A.L., Patterson, R.T., Falck, H., 2018. Organic matter control on the distribution of arsenic in lake sediments impacted by $\sim 65$ years of gold ore processing in subarctic Canada. Sci. Total Environ. 622-623, 1668-1679. https://doi.org/10.1016/j.scitotenv.2017.10.048

Golder Associates Ltd., 2008. Phase II Remedial Action Plan: Tundra Mine Site. http://www.mvlwb.ca/Registry.aspx?a=MV2009L8-0008

Golder Associates Ltd., 2016. Public Works and Government Services Canada Tundra Mine, NWT Remediation Environmental Monitoring Program: Water Quality: 2015 and Historical Results

Griffiths, K., Michelutti, N., Sugar, M., Douglas, M.S.V., Smol, J.P., 2017. Ice-cover is the principal driver of ecological change in High Arctic lakes and ponds. PLoS One 12. https://doi.org/10.1371/journal.pone.0172989

Groves, D.I., Goldfarb, R.J., Gebre-Mariam, M., Hagemann, S.G., Robert, F., 1998. Orogenic gold deposits - a proposed classification in the context of their crustal distribution and relationship to other gold deposit types. Ore Geology Reviews 13, 7-27. https://doi.org/10.1016/S0169-1368(97)00012-7

Hellweger, F.L., Farley, K.J., Lall, U., Di Toro, D.M., 2003. Greedy algae reduce arsenate. Limnol. Oceanogr. 48, 2275-2288. https://doi.org/10.4319/lo.2003.48.6.2275

Hoffmann, M., Mikutta, C., Kretzschmar, R., 2013. Arsenite binding to natural organic matter: Spectroscopic evidence for ligand exchange and ternary complex formation. Environ. Sci. Technol. 47, 12165-12173. https://doi.org/10.1021/es4023317

Huang, J.H., Ilgen, G., 2006. Factors affecting arsenic speciation in environmental samples: Sample drying and storage. Int. J. Environ. Anal. Chem. 86, 347-358. https://doi.org/10.1080/03067310500227878

INAC, 2005. Tundra Mine, NWT Environmental Monitoring Program: Water Quality Part D: 2005 Results. Prepared for: Contaminants and Remediation Directorate. Indian and Northern Affairs Canada. http://registry.mvlwb.ca/Documents/MV2005X0031/PartDWaterQualityMon-Nov05.pdf.

International Committee for Coal Petrology (ICCP), 1971. International Handbook of Coal. Petrography, 2nd ed. (1963); suppl. To 2nd ed.: Centre Nat. de Rech. Sci., Paris. 
Jamieson, H.E., Maitland, K.M., Oliver, J.T., Palmer, M.J., 2017. Regional distribution of arsenic in near-surface soils in the Yellowknife area. NWT Open File 2017-03.

Karunaratne, K. C. 2011. A field examination of climate-permafrost relations in continuous and discontinuous permafrost of the Slave geological province. Doctoral dissertation. Carleton University, Ottawa, Canada. https://curve.carleton.ca/a9c9335d-e1d8-4ffe-a772$4701 \mathrm{ab} 6 \mathrm{c} 2 \mathrm{f} 89$

Kirk, M.F., Holm, T.R., Park, J., Jin, Q., Sanford, R.A., Fouke, B.W., Bethke, C.M., 2004. Bacterial sulfate reduction limits natural arsenic contamination in groundwater. Geology 32, 953-956. https://doi.org/10.1130/G20842.1

Kirk, M.F., Roden, E.E., Crossey, L.J., Brealey, A.J., Spilde, M.N., 2010. Experimental analysis of arsenic precipitation during microbial sulfate and iron reduction in model aquifer sediment reactors. Geochim. Cosmochim. Acta 74, 2538-2555. https://doi.org/10.1016/j.gca.2010.02.002

Kleber, M., Eusterhues, K., Keiluweit, M., Mikutta, C., Mikutta, R., Nico, P.S., 2015. Mineral Organic Associations: Formation, Properties, and Relevance in Soil Environments, Advances in Agronomy. Elsevier Ltd. https://doi.org/10.1016/bs.agron.2014.10.005

Lafargue, E., Marquis, F., Pillot, D., 1998. Rock-Eval 6 Applications in hydrocarbon exploration, production, and soil contamination studies. Rev. l'Institut Français du Pétrole 53, 421-437. https://doi.org/10.2516/ogst:1998036

Lalonde, K., Mucci, A., Ouellet, A., Gélinas, Y., 2012. Preservation of organic matter in sediments promoted by iron. Nature 483, 198-200. https://doi.org/10.1038/nature10855

Langner, P., Mikutta, C., Kretzschmar, R., 2011. Arsenic sequestration by organic sulphur in peat. Nat. Geosci. 5, 66-73. https://doi.org/10.1038/ngeo1329

Lawson, M., Polya, D.A., Boyce, A.J., Bryant, C., Ballentine, C.J., 2016. Tracing organic matter composition and distribution and its role on arsenic release in shallow Cambodian groundwaters. Geochim. Cosmochim. Acta 178, 160-177. https://doi.org/10.1016/j.gca.2016.01.010

Le Pape, P., Blanchard, M., Brest, J., Boulliard, J.C., Ikogou, M., Stetten, L., Wang, S., Landrot, G., Morin, G., 2017. Arsenic Incorporation in Pyrite at Ambient Temperature at Both Tetrahedral S-I and Octahedral Fe (II) Sites: Evidence from EXAFS-DFT Analysis. Environ. Sci. Technol. 51, 150-158. https://doi.org/10.1021/acs.est.6b03502

Lopez, A.R., Funk, D.H., Buchwalter, D.B., 2017. Arsenic (V) bioconcentration kinetics in freshwater macroinvertebrates and periphyton is influenced by $\mathrm{pH}$. Environ. Pollut. 224, 82-88. https://doi.org/10.1016/j.envpol.2016.12.066

Lowers, H.A., Breit, G.N., Foster, A.L., Whitney, J., Yount, J., Uddin, M.N., Muneem, A.A., 2007. Arsenic incorporation into authigenic pyrite, Bengal Basin sediment, Bangladesh. Geochim. Cosmochim. Acta 71, 2699-2717. https://doi.org/10.1016/j.gca.2007.03.022 
Lynch, J., 1990. Provisional Elemental Values for Eight New Lake Sediment and Stream Sediment Reference STSD-3 and STSD-4". Geostand. Newsl. 14, 153-167.

Martin, A.J., Pedersen, T.F., 2002. Seasonal and interannual mobility of arsenic in a lake impacted by metal mining. Environ. Sci. Technol. 36, 1516-1523. https://doi.org/10.1021/es0108537

McGuire, A.D., Anderson, L.G., Christensen, T.R., Dallimore, S., Guo, L., Hayes, D.J., Heimann, M., Lorenson, T.D., Macdonald, R.W., Roulet, N., 2009. Sensitivity of the carbon cycle in the Arctic to climate change. Ecol. Monogr. 79, 523-555. https://doi.org/10.1890/08-2025.1

Miller, C.B., Parsons, M.B., Jamieson, H.E., Swindles, G.T., Nasser, N.A., Galloway, J.M., 2019. Lake-specific controls on the long-term stability of mining-related, legacy arsenic contamination and geochemical baselines in a changing northern environment, Tundra Mine, Northwest Territories, Canada. Appl. Geochemistry 109, 104403. https://doi.org/10.1016/j.apgeochem.2019.104403

Miller, C.B., Parsons, M.B., Jamieson, H.E., Ardakani, O.H., Gregory, B.R.B., Galloway, J.M., 2020. Influence of late-Holocene climate change on the solid-phase speciation and longterm stability of arsenic in sub-Arctic lake sediments. Science of the Total Environment, 136115, https://doi.org/10.1016/j.scitotenv.2019.136115

Mladenov, N., Zheng, Y., Simone, B., Bilinski, T.M., McKnight, D.M., Nemergut, D., Radloff, K.A., Rahman, M.M., Ahmed, K.M. 2015. Dissolved Organic Matter Quality in a Shallow Aquifer of Bangladesh: Implications for Arsenic Mobility. Environ. Sci. Technol. 49, 10815 - 10824. https://doi.org/10.1021/acs.est.5b01962

Moon, E.M., Peacock, C.L., 2012. Adsorption of Cu (II) to ferrihydrite and ferrihydrite bacteria composites: Importance of the carboxyl group for $\mathrm{Cu}$ mobility in natural environments. Geochim. Cosmochim. Acta 92, 203-219. https://doi.org/10.1016/j.gca.2012.06.012

Newville, M. 2019. Larch: Data Analysis Tools for X-ray Spectroscopy. Version 0.9.46. https://xraypy.github.io/xraylarch/

Outridge, P., Sanei, H., Goodarzi, F., 2007. Evidence for control of mercury accumulation rates in Canadian High Arctic lake sediments by variations of aquatic primary productivity. Enviromental Sci. Technlogy 41, 5259-5265. https://doi.org/10.1021/es070408x

Outridge, P.M., Sanei, H., Courtney Mustaphi, C.J., Gajewski, K., 2017. Holocene climate change influences on trace metal and organic matter geochemistry in the sediments of an Arctic lake over 7,000 years. Appl. Geochemistry 78, 35-48. https://doi.org/10.1016/j.apgeochem.2016.11.018

Palmer, M.J., Galloway, J.M., Jamieson, H.E., Patterson, R.T., Falck, H., Kokelj, S. V, 2015. The concentration of arsenic in lake waters of the Yellowknife area. NWT Open File 2015-06 29. https://doi.org/10.13140/RG.2.1.2582.5041 
Palmer, M.J., Chételat, J., Richardson, M., Jamieson, H.E., Galloway, J.M., 2019. Seasonal variation of arsenic and antimony in surface waters of small subarctic lakes impacted by legacy mining pollution near Yellowknife, NT, Canada. Sci. Total Environ. 684, 326339. https://doi.org/10.1016/j.scitotenv.2019.05.258

Palmer, M.J., Jamieson, H.E., Radková, A., Richardson, M., Maitland, K., Oliver, J., Falck, H. 2021. Mineralogical, geospatial, and statistical methods combined to estimate geochemical background of arsenic in soils for an area impacted by 60 years of mining pollution. Science of the Total Environment. 776, 145296. https://doi.org/10.1016/j.scitotenv.2021.145926

Parsons, M.B., LeBlanc, K.W.G., Hall, G.E.M., Sangster, A.L., Vaive, J., E, Pelchat, P., 2012. Environmental geochemistry of tailings, sediments and surface waters collected from 14 historical gold mining districts in Nova Scotia. Geological Survey of Canada, Open File Report 7150. https://doi.org/10.4095/291923

Parsons, M.B., Jamieson, H.E., Miller, C.B., and Galloway, J.M., 2019. Choosing an appropriate digestion protocol for environmental risk assessments of mineralized earth materials; Geological Survey of Canada, Scientific Presentation 97, 1 poster. https://doi.org/10.4095/314499

Planer-Friedrich, B., Wallschläger, D., 2009. A critical investigation of hydride generation-based arsenic speciation in sulfidic waters. Environ. Sci. Technol. 43, 5007-5013. https://doi.org/10.1021/es900111z

Prescher, C., Prakapenka, V.B., 2015. DIOPTAS : a program for reduction of two- dimensional X-ray diffraction data and data exploration. High Press. Res. 7959. https://doi.org/10.1080/08957959.2015.1059835

Prowse, T., Alfredsen, K., Beltaos, S., Bonsal, B., Duguay, C., Korhola, A., McNamara, J., Pienitz, R., Vincent, W.F., Vuglinsky, V., Weyhenmeyer, G.A., 2011. Past and future changes in arctic lake and river ice. Ambio 40, 53-62. https://doi.org/10.1007/s13280011-0216-7

PS Analytical, 2018. Available from: https://www.psanalytical.com/

Qu, C., Chen, W., Hu, X., Cai, P., Chen, C., Yu, X., 2019. Heavy metal behaviour at mineralorgano interfaces: Mechanisms, modelling and influence factors. Environ. Int. 131. https://doi.org/10.1016/j.envint.2019.104995

Ransom, A., Robb, M., 1986. The Salmita gold deposit, Courageous Lake, Northwest Territories. In: L.A. Clark and D.R. Francis (Editors), Gold in the Western Shield. Can. Inst. Min. Met., 38: 285-305

Rantala, M. V., Nevalainen, L., Rautio, M., Galkin, A., Luoto, T.P., 2016. Sources and controls of organic carbon in lakes across the subarctic treeline. Biogeochemistry 129, 235-253. https://doi.org/10.1007/s10533-016-0229-1 
950

951

952

953

954

955

956

957

958

959

960

961

962

963

964

965

966

967

968

969

970

971

972

973

974

975

976

977

978

979

980

981

982

983

984

985

986

987

Redman, A. D., Macalady, D. L., Ahmann, D. Natural organic matter affects arsenic speciation and sorption onto hematite. Environ. Sci. Technol. 2002, 36, 2889- 2896. https://doi.org/10.1021/es0112801

Reyes, J., Goodarzi, F., Sanei, H., Stasiuk, L.D., Duncan, W., 2006. Petrographic and geochemical characteristics of organic matter associated with stream sediments in Trail area British Columbia, Canada. Int. J. Coal Geol. 65, 146-157. https://doi.org/10.1016/j.coal.2005.04.016

Riedel, T., Zak, D., Biester, H., Dittmar, T., 2013. Iron traps terrestrially derived dissolved organic matter at redox interfaces. Proc. Natl. Acad. Sci. 110, 10101-10105. https://doi.org/10.1073/pnas.1221487110

Ritter, K., Aiken, G.R., Ranville, J.F., Bauer, M., Macalady, D.L., 2006. Evidence for the aquatic binding of arsenate by natural organic matter-suspended Fe (III). Environ. Sci. Technol. 40, 5380-5387. https://doi.org/10.1021/es0519334

Rönnhult, T., Brox, B., Fritze, G., 1987. The influence of surface topography on the x-ray intensity in electron microprobe analysis (EDS/WDS). Scanning 9, 81-87. https://doi.org/10.1002/sca.4950090205

Sanei, H., Ardakani, O.H., 2016. Alteration of organic matter by ion milling. Int. J. Coal Geol. 163, 123-131. https://doi.org/10.1016/j.coal.2016.06.021

Sanei, H., Stasiuk, L.D., Goodarzi, F., 2005. Petrological changes occurring in organic matter from recent lacustrine sediments during thermal alteration by Rock-Eval pyrolysis. Org.

Schuh, C.E., Jamieson, H.E., Palmer, M.J., Martin, A.J., 2018. Solid-phase speciation and postdepositional mobility of arsenic in lake sediments impacted by ore roasting at legacy gold mines in the Yellowknife area, Northwest Territories, Canada. Appl. Geochemistry 91, 208-220. https://doi.org/10.1016/j.apgeochem.2017.10.025

Schuh, C.E., Jamieson, H.E., Palmer, M.J., Martin, A.J., Blais, J.M., 2019. Controls governing the spatial distribution of sediment arsenic concentrations and solid-phase speciation in a lake impacted by legacy mining pollution. Sci. Total Environ. 654, 563-575. https://doi.org/10.1016/j.scitotenv.2018.11.065

Seabridge Gold Inc., 2010. Courageous Lake Project Description in Support of a Class " A " Land Use Permit (Former Permit MV2003C0050).

Sharma, P., Rolle, M., Kocar, B.D., Fendorf, S., Kapppler, A., 2010. Influence of Natural Organic Matter on As Transport and Retention. Environ. Sci. Technol. 45, 546-553. https://doi.org/10.2134/jeq2003.1393

Shirokova, L. S., Pokrovsky, O. S., Moreva, O. Y., Chupakov, A. V., Zabelina, S. A., Klimov, S. I., Vorobieva, T. Y. (2013). Decrease of concentration and colloidal fraction of organic carbon and trace elements in response to the anomalously hot summer 2010 in a humic boreal lake. Sci Total Environ, 463-464, 78-90. https://doi:10.1016/j.scitotenv.2013.05.088 
Silke, R., 2009. The Operational History of Mines in the Northwest Territories, Canada, pp. 487 - 500. http://miningnorth.com/_rsc/sitecontent/library/NWT_Mines_History_RSilke2009.pdf

Smedley, P.L., Kinniburgh, D.G., 2002. A review of the source, behaviour and distribution of arsenic in natural waters. Appl. Geochemistry 17, 517-568. https://doi.org/10.1016/S0883-2927(02)00018-5

Staples, R., 2014. Tundra Mine, NWT Remediation Environmental Monitoring Program: Water Quality Part L: 2013 and Historic Results

Stern, G.A., Macdonald, R.W., Outridge, P.M., Wilson, S., Chételat, J., Cole, A., Hintelmann, H., Loseto, L.L., Steffen, A., Wang, F., Zdanowicz, C., 2012. How does climate change influence arctic mercury? Sci. Total Environ. 414, 22-42. https://doi.org/10.1016/j.scitotenv.2011.10.039

Sundman, A., Karlsson, T., Sjoberg, S., Persson, P., 2014. Complexation and precipitation reactions in the ternary As (V)-Fe (III)-OM (organic matter) system. Geochim. Cosmochim. Acta 145, 297-314. https://doi.org/10.1016/j.gca.2014.09.036

Tessier, A., Fortin, D., Belzile, N., DeVitre, R.R., Leppard, G.G., 1996. Metal sorption to diagenetic iron and manganese oxyhydroxides and associated organic matter: Narrowing the gap between field and laboratory measurements. Geochim. Cosmochim. Acta 60, 387-404. https://doi.org/10.1016/0016-7037(95)00413-0

Toevs, G.R., Morra, M.J., Polizzotto, M.L., Strawn, D.G., Bostick, B.C., Fendorf, S., 2006. Metal(loid) diagenesis in mine-impacted sediments of lake Coeur d'Alene, Idaho. Environ. Sci. Technol. 40, 2537-2543. https://doi.org/10.1021/es051781c

URS, 2005. Geochemical Assessment of Acid Rock Drainage and Metal Leaching Potential of Tailings and Waste Rock, Tundra Mine, NWT.

Van Den Berghe, M.D., Jamieson, H.E., Palmer, M.J., 2018. Arsenic mobility and characterization in lakes impacted by gold ore roasting, Yellowknife, NWT, Canada. Environ. Pollut. 234, 630-641. https://doi.org/10.1016/j.envpol.2017.11.062

Vega, A.S., Planer-Friedrich, B., Pastén, P.A., 2017. Arsenite and arsenate immobilization by preformed and concurrently formed disordered mackinawite (FeS). Chem. Geol. 475, 6275. https://doi.org/10.1016/j.chemgeo.2017.10.032

Wagemann, R., Snow, N.B., Rosenberg, D.M., Lutz, A., 1978. Arsenic in sediments, water and aquatic biota from lakes in the vicinity of Yellowknife, Northwest Territories, Canada. Arch. Environ. Contam. Toxicol. 7, 169-191. https://doi.org/10.1007/BF02332047

Wang, S., Mulligan, C.N., 2006. Effect of natural organic matter on arsenic release from soils and sediments into groundwater. Environ. Geochem. Health 28, 197-214. https://doi.org/10.1007/s10653-005-9032-y

Wang, Y., Le Pape, P., Morin, G., Asta, M., King, G., Bartova, B., Suvorova, E., Frutschi, M., Ikogou, M., Hoai, V., Pham, C., Le Vo, P., Herman, F., Charlet, L., Bernier-Latmani, R., 
2018. Arsenic speciation in Mekong Delta sediments depends on their depositional environment. Environ. Sci. Technol. 52, 3431-3439. https://doi.org/10.1021/acs.est.7b05177

Wolthers, M., Charlet, L., Van Der Weijden, C.H., Van Der Linde, P.R., Rickard, D., 2005. Arsenic mobility in the ambient sulfidic environment: Sorption of arsenic (V) and arsenic (III) onto disordered mackinawite. Geochim. Cosmochim. Acta 69, 3483-3492. https://doi.org/10.1016/j.gca.2005.03.003 


\section{Supplementary Files}

This is a list of supplementary files associated with this preprint. Click to download.

- GraphicalAbstact.png

- Milleretal2021EESSupplementalData.docx 